Róisín Mulgrew, 'The costs of suspicion: a critical analysis of the compensation scheme established by Article 85(3) of the Rome Statute'

This paper was published as a book chapter (Chapter 19) in Róisín Mulgrew and Denis Abels (eds.) Research Handbook on the International Penal System (Edward Elgar Publishing, 2016) 


\section{The costs of suspicion: a critical analysis of the compensation scheme established by Article 85(3) of the Rome Statute}

Róisín Mulgrew

\section{Introduction}

The ICC was established to prosecute and punish persons guilty of the most serious crimes known to mankind. To facilitate this objective, suspects are arrested and transferred to the seat of the Court and, often, remanded in detention throughout their trial. As with national criminal justice systems, international prosecutions do not necessarily result in convictions. Proceedings may be terminated for a variety of reasons and acquittals can be handed down at either first instance or on appeal. The Rome Statute (ICCSt), for the first time in international criminal law, contains a compensation scheme for arrested or convicted persons.

Article 85 empowers the ICC to provide compensation for the deprivation of liberty in three situations: unlawful arrest or detention (Article 85(1)), wrongful conviction (Article 85(2)) and, in exceptional circumstances, acquittal or termination of proceedings due to a grave and manifest miscarriage of justice (Article 85(3)). As they reflect, and indeed, virtually repeat verbatim, existing and customary human rights remedies, ${ }^{1}$ the former two provisions are not controversial. Article 85(3), on the other hand, goes beyond contemporary human rights law.

In contrast to the ease with which delegates at the Rome Conference were willing to accept statutory provisions that reflected contemporary international treaty law, ${ }^{2}$ there was no consensus in relation to the proposal to adopt a provision granting a power to compensate acquitted persons. Article 85(3) originated from a Japanese proposal at PrepCom to compensate persons pronounced innocent and those detained but never prosecuted. ${ }^{3}$ The lack of agreement on this power was demonstrated by the fact that the proposed provision was entirely in square brackets. ${ }^{4}$ States were concerned that such a power would adversely impact on Prosecutorial discretion to bring proceedings, and accordingly, if such a compensatory power was to be granted by the statute, that it should be restricted to instances of malicious prosecution. ${ }^{5}$

Given these concerns and the fact that there was no legal duty to provide for compensation of this kind, Article 85(3) must be welcomed as an innovative and progressive development of international (criminal) law. The decision to include a

\footnotetext{
${ }^{1}$ See Arts. 9(5) \& 14(6) ICCPR; Art. 5(5) ECHR; Art. 3 Protocol No 7 ECHR.

${ }^{2}$ See Y. Kim, The International Criminal Court: A Commentary of the Rome Statute (Wisdom House Publishing 2003) 459; S. Zappalà, 'Compensation to an Arrested or Convicted Person', in A. Cassese, P. Gaeta and J. Jones (eds) The Rome Statute of the ICC (Oxford University Press 2002) 1577, 1578.

${ }^{3}$ W. Schabas The International Criminal Court: A Commentary on the Rome Statute (Oxford University Press 2010) 965.

${ }^{4}$ Ibid.

${ }^{5} \mathrm{Kim}$ (n 2) 460.
} 
statutory power to award compensation to acquitted persons or persons against whom proceedings have been terminated can be understood in light of the particularities of the international criminal justice system and the need to bridge a remedial gap in the international legal framework. The provision does not, however, grant a right to such persons and the judicial power to grant an award is restricted by a number of statutory and regulatory fetters.

This chapter examines the scope of this new remedial power in international criminal law, analysing the reasons for its adoption, the limits on its use and the need to rethink the form and nature of the delivery of redress in this context. In other words it explores the legal, practical and personal costs of suspicion in the international criminal justice context for both suspects and the prosecuting institution.

\section{Reasons for adopting Article 85(3): the particularities of the international criminal justice context}

In addition to the general reasons in favour of adopting a compensation scheme for victims of mistakes of criminal justice process, there are reasons particular to the international criminal justice system that support the inclusion of this remedial power in the ICCSt. These particularities include the acquittal rate, the practice in relation to terminating proceedings, the use and impact of international remand detention and the difficulties encountered when trying to relocate acquitted persons after release from such detention.

\section{$\underline{2.1 \text { Fallibility of international criminal justice process }}$}

If the facts and figures of the UN ad hoc tribunals provide an indication of what the ICC can expect, then it is clear that a compensation scheme for acquitted accused persons is a very welcome development. At both institutions, the acquittal rate was over $20 \%$ of completed cases.

The ICTY issued 161 indictments. However, as 36 indictments were withdrawn, some cases are on-going and thirteen cases have been transferred to national jurisdictions - the number of completed cases is much smaller. Of the 97 completed cases to date, ${ }^{6}$ eighteen persons have been acquitted on all counts. Eleven persons were acquitted on all counts at first instance. ${ }^{7}$ Some of these acquittals were confirmed on appeal, ${ }^{8}$ and two acquittals were confirmed following a retrial ordered

\footnotetext{
631 March 2015.

${ }^{7}$ Dragan Papić, Zejnil Delalić, Fatmir Limaj, Isak Musliu, Sefer Halilović, Miroslav Radić, Ljube Boškoksi, Ivan Cermak, Ramush Haradinaj, Idriz Balaj.

${ }^{8}$ Zejnil Delalić, Fatmir Limaj, Isak Musliu, Sefer Halilović, Ljube Boškoksi.
} 
by the Appeals Chamber. ${ }^{9}$ Seven persons had their convictions (and sentences ranging from 2-27 years) reversed by the Appeals Chamber. ${ }^{10}$

The ICTR issued 93 indictments in total. Of these, seven cases are on-going, nine fugitives remain, four persons were transferred to national jurisdictions and two persons died before the conclusion of their trial. Of the 71 finalised cases, fourteen persons were acquitted on all charges and released. At first instance, six accused persons were unanimously acquitted on all counts. ${ }^{11}$ Several unanimous first instance acquittals were confirmed on appeal, ${ }^{12}$ although some by majority decision. ${ }^{13}$ Some acquittals were the result of the reversal of convictions on appeal. Justin Mugenzi and Prosper Mugiraneza had their 30 year sentences overturned by a majority decision. ${ }^{14}$ The convictions of Ndindiliyimana, Nzuwonemeye and Zigiranyirazo were unanimously reversed and a verdict of not guilty entered by the Appeals Chamber. ${ }^{15}$

At the ICC, of the three completed cases to date, one (Mr Ngudjolo) has resulted in a unanimous acquittal on all counts at first instance, ${ }^{16}$ which was affirmed by a majority decision by the Appeals Chamber. ${ }^{17}$

These figures reveal a high acquittal rate at international criminal courts and strengthen arguments in support of establishing a compensation scheme for acquitted persons. The provision adopted by the ICCSt is not, however, limited to instances of acquittal.

\section{$\underline{2.2 \text { Termination of proceedings }}$}

Article 85(3) may also be used to provide redress to persons who have been released from detention following the termination of proceedings against them because of a grave and manifest miscarriage of justice. The case-law of the ad hoc tribunals provides some examples of scenarios that would potentially qualify under this heading.

The majority of the 36 indictments withdrawn at the ICTY were withdrawn against indictees that were not in the custody of the Tribunal due to either their

\footnotetext{
${ }^{9}$ Ramush Haradinaj, Idriz Balaj.

${ }^{10}$ Zoran Kupreškić (10), Mirjan Kupreškić (8) and Vlatko Kupreškić (6), Naser Orić (2), Ante Gotovina (24) and Mladen Markač (18), Momčilo Perišić (27).

${ }^{11}$ Jean Mpambara, Hormisdas Nsengimana, Andre Rwamakuba, Gratien Kabiligi, Casimir Bizimungu, Jérôme Bicamumpaka.

${ }^{12}$ Emmanuel Bagambiki and André Ntagerura (Trial Chamber February 2004 - Appeal Chamber July 2006 - unanimous dismissal of Prosecutor appeal (following previous dismissal of appeal of acquittal in February 2006); Bagilishmena ICTR-95-1A-A (Judgment, 3 July 2002).

${ }^{13}$ Separate and Dissenting Opinion of Judge Mehmet Güney in Bagilishema ICTR-95-1A-T

(Judgment, 7 June 2001) - he agreed with the majority's decision to acquit on some but not all counts.

${ }^{14}$ Dissenting opinion of Judge Liu Dagun - uphold TC convictions in Mugenzi and Mugiraneza ICTR99-50-A (Judgment, 4 February 2013).

${ }^{15}$ See Ndindiliyimana, Nzuwonemeye and Sagahutu ICTR-00-56-A (Judgment, 11 February 2014); Zigiranyirazo ICTR-01-73-A (Judgment, 16 November 2009).

${ }^{16}$ Chui ICC-01/04-02/12-3-tENG (Judgment pursuant to article 74 of the Statute, 18 December 2012).

${ }^{17}$ Chui ICC-01/04-02/12 A (Judgment on the Prosecutors appeal against the decision of Trial Chamber II entitled 'Judgment pursuant to article 74 of the Statute', 27 February 2015).
} 
(suspected) death or the re-evaluation of prosecutorial strategy to focus on high-level perpetrators. ${ }^{18}$ At the ICTR, the only instance where the charges were withdrawn in cases other than of persons who had deceased involved decisions to withdraw indictments to facilitate investigations and prosecutions by national authorities in Belgium. ${ }^{19}$ Several proceedings have also been terminated at the ICC due to evidence of the death of the suspect. ${ }^{20}$ Such cases would not fall within the scope of Article $85(3)$.

There were, however, some notable cases of indictments being withdrawn after indictees had spent time in international custody. At the ICTY, for example, Marinko Katava, Pero Skopljak and Ivan Šantić spent between 2 and 3 months in the UNDU following their voluntary surrender. Nenad Banović spent 5 months in remand custody in The Hague following his arrest. In all of these cases, the Prosecutor sought leave to withdraw the indictments due to having an insufficient evidential basis to justify or continue proceedings. In the decisions ordering their release, while the judges accepted the right of the Prosecutor to conduct investigations, they noted the emergency of such situations and warned the Prosecutor to in future 'act expeditiously on matters of such fundamental importance as the liberty of the accused'. ${ }^{21}$ Moreover, it was in the 'interests of justice to restore $(\ldots$ ) [their] right to liberty without delay'. ${ }^{22}$ These situations (whereby indictees have spent time in custody before proceedings were terminated) provide examples of cases that could fall within the scope of Article 85(3).

There have also been examples of the wrong person being remanded in custody. In 1996, Goran Lajić's release from the UNDU and transfer back to Germany was ordered after the Prosecutor realised he was the wrong person. ${ }^{23}$ Agim Murtezi spent 10 days at the UNDU following his arrest by KFOR in Kosovo, before being released after the realisation that this was a case of mistaken identity. ${ }^{24}$ These cases provide clear examples of situations that could and should fall within the scope of Article 85(3).

It is important to note, however, that Article 85(3) refers to the termination of proceedings, and not the withdrawal of indictments. At the ICTY, indictments were

\footnotetext{
${ }^{18}$ See 'Order granting leave for withdrawal of charges against Nikica Janjic, Dragan Kondić, Goran Lajić, Dragomir Saponja and Nedjelko Timarac' (5 May 1998); Statement by the Prosecutor following the Withdrawal of the Charges against 14 accused, CC/PIU/314-e (OTP Press release, 8 May 1998 [Mirko Babić, Zdravko Govedarica, Gruban, Predrag Kostić, Nedeljko Paspalj, Milan Pavlić, Milutin Popović, Draženko Predojević, Zeljko Savić]. IT-95-15-I (Order authorising the withdrawal of the indictment against Zoran Marinić, 3 October 2002).

${ }^{19}$ Bernard Ntuyahaga (ICTR-98-40) and Leonidas Rusatira (ICTR-02-80).

${ }^{20}$ Kony et al ICC-02-04-01/05 (Decision to terminate proceedings against Raska Lukwiya, 11 July 2007) [Uganda]; Nourain ICC-02/05-03/09 [Sudan] terminated by TCIV on 4 October 2013; Gaddafi [Libya] Terminated 22 November 2011.

${ }^{21}$ See Katava IT-95-16-PT (Decision on motion by the Prosecutor for withdrawal of indictment against Marinko Katava, 19 December 1997).

${ }^{22}$ See Banović IT-95-8/1-PT (Decision on the motion of the Prosecution to withdraw the indictment against Nenad Banović, 10 April 2002).

${ }^{23}$ See 'Goran Lajic returned to Germany' (Press Release CC/PIO/090-E, 18 June 1996).

${ }^{24}$ See 'Statement on behalf of Agim Murtezi' (Press Release P.I.S/733-E, 25 February 2003); 'Agim Murtezi released following the withdrawal of the indictment against him' (Press Release CC/P.I.S/736E, 28 February 2003).
} 
withdrawn due to a lack of evidence without prejudice to the Prosecutor's right to bring the same or similar charges again at some point in the future if sufficient additional evidence became available. ${ }^{25}$ This practice has been replicated at the ICC. In the Kenyatta case, the Prosecutor sought the withdrawal of charges due to a lack of evidence and the Trial Chamber's refusal to grant an adjournment until such time as the Kenyan Government cooperates. ${ }^{26}$ Even in this situation, the withdrawal of charges was 'without prejudice to the possibility of bringing new charges at a later date based on the same or similar factual circumstances' on the basis of additional evidence. $^{27}$

There have also been instances where the Pre-Trial Chamber has refused to confirm the charges against an individual without prejudice to the Prosecutor's right to request confirmation of charges at a later date if additional evidence is presented. ${ }^{28}$

Decisions declining to confirm or to withdraw charges (to date) have had a suspensive effect only. Moreover, this legal limbo does not seem to have a maximum permitted time-frame. As proceedings are not terminated, the indictment remains open. Formalised suspicion and stigma remains, as does the potentially indefinite threat of future prosecution and detention. This approach also bars such suspects from applying for compensation under Article 85(3). This is significant given that such individuals may have spent time in international custody pending the PTC decision. For example, Mr Mbarumshimana spent 11 months in custody at the ICCDC before being released five days after a majority decision by PTC III refusing to confirm charges against him. ${ }^{29}$ Reliance on, and the potentially excessive length of, international remand custody are important reasons to support the adoption of Article 85(3).

\subsection{The use of international remand detention}

The compensation scheme established by Article 85(3) aims to remedy the consequences of grave and manifest miscarriages of justice. One of the most visible consequences of such an injustice is likely to be the excessively long period of time accused persons typically spend in custody pending finalisation of the case against them. For example at the ICTY, Zejnil Delalić spend 1000 days in custody, mostly in isolation, ${ }^{30}$ before being acquitted on all counts at first instance (confirmed at appeal

\footnotetext{
25 'Indictment against Milan Zec Withdrawn' (Press Release JL/P.I.S/691e, 27 July 2002).

${ }^{26}$ Kenyatta ICC-01/09-02-01 [KenyaNotice of withdrawal of charges against Uhuru Muigai Kenyatta, 5 December 2014) para 2.

${ }^{27}$ Kenyatta ICC-01/09-02-01 [Kenya] (Notice of withdrawal of charges against Uhuru Muigai Kenyatta, 5 December 2014) para 3.

${ }^{28}$ Abu Garda ICC-02/05-02/09 [Sudan] (Decision on the Confirmation of Charges, 8 February 2010) para 236.

${ }^{29}$ Mbarumshimana ICC-01/04-01/10 [DRC] (Decision on Confirmation of Charges, 16 December 2011).

${ }^{30}$ See S. Beresford 'Redressing the Wrongs of the International Justice System' (2002) 96(3) AJIL 628, 629.
} 
proceedings). ${ }^{31}$ Three members of the Kupreškić family (brothers Zoran and Mirjan and cousin Vlatko) each spent four years behind bars at the UNDU (6 October /December 1997 - 23 October 2001) before being unanimously acquitted on all counts on appeal. ${ }^{32}$ Naser Orić was sentenced to two years imprisonment at first instance. As he had already been in custody at the UNDU for longer than the sentence imposed (three years, two months and 21 days), he was released immediately. ${ }^{33}$ Two years later, the Appeals Chamber unanimously reversed his conviction, finding him not guilty on all counts. ${ }^{34}$

Likewise at the ICTR, some individuals who were unanimously acquitted on all counts at first instance had spent five, ${ }^{35}$ seven, ${ }^{36}$ eight, ${ }^{37}$ eleven ${ }^{38}$ and twelve years ${ }^{39}$ in remand detention at the UNDF. When the cases of persons who were acquitted on appeal are analysed, the situation becomes more serious. Nzuwonemeye, for example, spent nearly 14 years in custody before being acquitted on all counts on appeal. ${ }^{40}$ His co-accused, Ndindiliyimana, had been released following sentencing at first instance as he had already served the sentence imposed (eleven years). Between them they had served a quarter of a century in custody for crimes they were found not guilty of committing. ${ }^{41}$

This problem has continued at the ICC. Mr Ngudjolo was detained for nearly five years (7 February 2008 - 21 December 2012) before his release from the ICCDC following his acquittal at first instance. Although the ICC rejected the Prosecutor's motion to have Mr Ngudjolo detained pending the outcome of the appeal, ${ }^{42} \mathrm{Mr}$ Ngudjolo was placed in administrative detention by the Host State following his release (see below).

The length of such detention, attributed to the 'long and complex trials', ${ }^{43}$ is aggravated by the difficulties involved with getting provisional release in the international context ${ }^{44}$ and the fact that such detention occurs in a foreign country. While there are examples of acquitted persons at the UN Tribunals who were granted

\footnotetext{
${ }^{31}$ Delalić, Mucić, Delić and Landžo IT-96-21-T (Judgment, 16 November 1998).

${ }^{32}$ Kupreškić et al IT-95-16-A (Judgment, 23 October 2001).

${ }^{33}$ Orić IT-03-68-T (Judgment, 30 June 2006) para 784.

${ }^{34}$ Orić IT-03-68-A (Judgment, 3 July 2008).

${ }^{35}$ Mpambara ICTR-01-65-T (Judgment, 11 September 2006).

${ }^{36}$ Nsengimana ICTR-01-09-T (Judgment, 17 November 2009).

${ }^{37}$ Rwamakuba ICTR-98-44C-T (Judgment, 20 September 2006).

${ }^{38}$ Bagosora, Kabiligi, Ntabakube, Nsengiyumva ICTR-98-41-T (Judgment and Sentence, 18 December 08).

${ }^{39}$ Casimir Bizimungu, Jérôme Bicamumpaka. See Bizimungu, Mugenzi, Bicamumpaka, Mugiraneza ICTR-99-50-T (Judgment and Sentence, 30 September 2011).

${ }^{40}$ See Nzuwonemeye ICTR-00-56-A (Motion for Compensation and Damages for Violations of the Fundamental Rights of F.X. Nzuwonemeye pursuant to SCRes 1966 (2010), MICT-13-43, 18 February 2015).

${ }^{41}$ See Ndindiliyimana, Nzuwonemeye, Sagahutu ICTR-00-56-A (Judgment, 11 February 2014).

42 ICC-01/04-02/12-12 (Decision on the request of the Prosecutor of 19 December 2012 for suspensive effect, 20 December 2012).

${ }^{43}$ Rwamakuba ICTR-98-44C-T (Decision on Appropriate Remedy, 31 January 2007) para 29.

${ }^{44}$ Provisional release was almost never granted in the early years of the UN Tribunals due to the inclusion of the term 'exceptional circumstances' in Rule 65, although this did improve for ICTY prisoners in later years. See A. Trotter, 'Provisional release from international remand detention', Chapter 2 in this volume.
} 
extensive and numerous periods of provisional release ${ }^{45}$ many (of these) accused persons were denied provisional release throughout their period of detention. ${ }^{46}$

Accused persons at the ICC can apply for release pending trial, and any decision in this regard must be reviewed every 120 days. ${ }^{47}$ The legal procedure does not, however, address the practical and legal problem that the Host State is reluctant to facilitate the provisional release of international suspects onto its territory. The ICC has had to conclude bilateral agreements with third States to facilitate such release. ${ }^{48}$

The realities of the international context mean that it is foreseeable that acquitted accused persons may spend longer in detention than a convicted person at the national level. While no-one would argue that such lengthy detention in a foreign country is not a serious burden to be imposed on accused persons, it has continually been upheld as lawful by international criminal courts.

While detention infringes upon the right to liberty, this right is not absolute. Detention on the basis of a reasonable suspicion is an explicitly recognised ground for liberty deprivation in human rights law. ${ }^{49}$ International criminal procedure aims to verify that reasonable suspicion exists and thereby ensure the legality of international detention. In contrast to the procedure of the UN Tribunals, whereby an arrest warrant was issued after the judicial confirmation of an indictment, ${ }^{50}$ a Pre-Trial Chamber of the ICC issues the arrest warrant before a hearing for the confirmation of charges. ${ }^{51}$ An arrest warrant can be issued where there are reasonable grounds to believe the person committed crimes and if it is necessary to ensure attendance at trial, to prevent the obstruction of investigations or the commission of related crimes. ${ }^{52}$

Reasonable suspicion, however, only legitimises the initial detention. Continued detention requires additional justification on relevant grounds of public interest such as the prevention of the commission of further offences, flight of the accused, social disturbance or interference with the administration of justice. ${ }^{53}$ Significantly for the purposes of this chapter, it is important to note that 'a subsequent acquittal does not render the earlier determination of a detention-justifying ground illegitimate'. ${ }^{54}$

\footnotetext{
${ }^{45}$ For example, following his voluntary surrender to the ICTY in March 2005, Momčilo Perišić was granted provisional release from the 9 June 2005 - 18 September 2008, and on these subsequent occasions before his conviction by the Trial Chamber in September 2011 (22 December 2008 - 9 January 2009; 9-17 April 2009; 25 July 2009- 14 August 2009; 9 December 2009-14 January 2010; 23 July 2010-19 August 2010; 23 July 2010- 19 August 2010).

${ }^{46}$ See Trotter (n 44).

${ }^{47}$ Art. 60(2)-(3) ICCSt.

${ }^{48}$ ICC and Belgium.

${ }^{49}$ Art. 5(1)(c) ECHR.

${ }^{50}$ See Arts. 18(4), 19(1)-(2), 20(2) ICTYSt; Arts. 17(4), 18(2) and 19 ICTRSt.

${ }^{51}$ See Arts. 58(1), 60(1), 61(1), (6) ICCSt.

${ }^{52}$ Art. 58(1) ICCSt.

${ }^{53}$ See Smirnova v Russia App nos 46133/99 and 48183/99 (ECtHR, 24 July 2003) paras 58-9; $W v$ Switzerland App no 14379/88 (ECtHR, 26 January 1993) para 30; Letellier v France App no 12369/86 (ECtHR, 26 June 1991) paras 35, 43, 51; Neumeister v Austria App no 1936/63 (ECtHR, 27 June 1968) para 10; Matznetter v Austria App no 2178/ 64 (ECtHR, 10 November 1969) para 9.

${ }^{54}$ J. Michels, 'Compensating Acquitted Defendants for Detention before International Criminal Courts' (2010) 8 Journal of International Criminal Justice 407, 411.
} 
The repeated judicial affirmations of the lawfulness of such lengthy periods of detention by international courts, however, stretches human rights thresholds to their limits and such practice is viewed by many as a way of avoiding the need to acknowledge rights violations that would require the release of indicted or accused persons (see below).

There have been strong dissenting opinions in relation to whether acquitted accused persons' rights have been violated by lengthy detention. ${ }^{55}$ These opinions referred, however, to fair trial rights rather than the right to liberty. Even then, the focus was on the length of time taken to render judgment following the close of argument (three years; two years and ten months), and not the overall length of proceedings (which were considered acceptable due to their complex and litigious nature). Judge Short highlighted the fact that the right to trial without delay was important, not only to serve the interests of justice, but to avoid keeping accused persons in a 'state of uncertainty as to their fate ( . . . ) [where] the Accused have been incarcerated without judgement for more than twelve years' ${ }^{56}$ In this particular case, the two co-accused persons, who had been sentenced to 30 years in prison, had their convictions overturned by majority decision, ${ }^{57}$ nearly fourteen years after their arrest and transfer to the ICTR. ${ }^{58}$

Therefore, even though human rights law recognises that detention for an unjustifiably long period renders it unlawful, ${ }^{59}$ the international criminal courts have relied on human rights jurisprudence that has accepted the lawfulness of lengthy periods of detention by national authorities in particular cases to justify an overall policy of lengthy pre-judgment detention.

Although European penal policy explicitly warns against adopting such a policy in relation to foreign prisoners, ${ }^{60}$ lengthy detention is likely to continue to be considered necessary for the majority of internationally accused persons for a number of reasons: the gravity of the charges against them; their perceived risk of flight or interference with witnesses or evidence; and the lack of an international police force to secure attendance at trial by re-arrest. ${ }^{61}$

\footnotetext{
${ }^{55}$ See the Partially Dissenting Opinion of Judge Emile Francis Short, Bizimungu, Mugenzi, Bicamumpaka, Mugiraneza ICTR-99-50-T (Judgment and Sentence, 30 September 2011); Partially Dissenting opinion of Judge Patrick Robinson in Mugenzi and Mugiraneza ICTR-99-50-A (Judgment, 4 February 2013).

${ }^{56}$ Partially Dissenting Opinion of Judge Emile Francis Short, Bizimungu, Mugenzi, Bicamumpaka, Mugiraneza ICTR-99-50-T (Judgment and Sentence, 30 September 2011) para 6.

${ }^{57}$ Dissenting opinion of Judge Liu Dagun - upheld the TC convictions in Mugenzi and Mugiraneza ICTR-99-50-A (Judgment, 4 February 2013).

${ }^{58}$ Mugenzi and Mugiraneza ICTR-99-50-A (Judgment, 4 February 2013).

${ }^{59}$ See Smirnova v Russia App nos 46133/99 and 48183/99 (ECtHR, 24 July 2003) para 62; Wemhoff $v$ Germany App no 2122/64 (ECtHR, 27 June 1968) para 5.

${ }^{60}$ See Rules 5 and 13 Committee of Ministers Recommendation CM/Rec(2012) 12 concerning foreign prisoners.

${ }^{61}$ See Bemba Gombo et al ICC-01/05-01/13 OA 10 (Judgment on the appeal of the Prosecutor against the decision of the PTC II of 23 January 2015 entitled 'Decision on 'Mr Bemba's Request for provisional release', 29 May 2015); Michels (n 54) 414.
} 
The presence of reasonable suspicion and the operational realities of the international criminal justice system are likely to 'inoculate' ${ }^{62}$ international courts from the majority of claims for excessive detention. The judicial acceptance of the technical legality of such detention (or indeed, their refusal to acknowledge its unlawfulness) does not negate the very real and detrimental impact an international indictment and the resulting detention can have on accused persons and their families.

\subsection{The impact of international detention}

Whether the former suspect has been acquitted or had proceedings against them terminated, Article 85(3) can only be relied upon by claimants who have been detained by the ICC. Compensation under this scheme is intended to provide redress for consequences that derive from the detention associated with the grave and manifest miscarriage of justice.

Persons who fall within the scope of Article 85(3) will have lost things that 'cannot be retrieved'. ${ }^{63}$ Acquitted accused persons have endured the loss of liberty, interference with their family life and careers, been subjected to the defamatory effects of global and public accusations of the highest form of criminality, the mental anguish of prosecution and the indignities of detention. Moreover, as Sheehy notes, the detention of an innocent person may have a more detrimental impact than the detention of a guilty person: the injustice of the incarceration inflicts greater moral harm. ${ }^{64}$ Vlatko Kupreškić (acquitted on all counts on appeal at the ICTY) explained that, 'as far as I am concerned, four years of my life have been destroyed. My family, my mother and my businesses have been devastated' ${ }^{65}$ International detention not only deprives individuals of their liberty and freedom of movement; it deprives people of the fundamental aspects of human life - relationships, personal and professional fulfilment. Moreover, it imposes negative costs, such as the loss of life opportunities and exposure to increased risks of physical and mental health issues. ${ }^{66}$

While international detention regimes are very liberal, this does not detract from the fact that internationally accused persons are held in custody in a foreign country away from their homes and families, accused of the worst crimes known to mankind, with the uncertainty of their fate drawn out over many years. As Manns notes, 'the psychological impact of the loss of liberty and degradations of imprisonment may be

\footnotetext{
${ }^{62}$ J. Manns, 'Liberty Takings: A Framework for Compensating Pre-trial Detainees' (2005) 512 The Harvard John M. Olin Discussion Paper Series 34.

${ }^{63}$ Justice Johnson quoted in Kimberly N. Grant 'Ten Dollars for Twenty-Four Years: Providing Justice for Exonerees Using Victim-Oriented Mediation’ (2008) 15 Dispute Resolution Magazine 19, 20.

${ }^{64}$ C. Sheehy, 'Compensation for Wrongful Conviction in New Zealand' (1996-1999) 8 Auckland University Law Review 977, 983; K. Campbell and M. Denov, 'The Burden of Innocence: Coping with a Wrongful Imprisonment' (2004) Canadian Journal of Criminology and Criminal Justice 139, 145.

${ }^{65}$ E. Tinjak, 'Former Defendants Fight for Damages' (2011) Institute for War \& Peace Reporting available online <http://iwpr.net/print/report-news/regional-report-former-defendants-fight-damages> accessed 8 August 2015.

${ }^{66}$ See A. Grounds, 'Understanding the Effects of Wrongful Imprisonment' (2005) 32 Crime and Justice 1, 3 .
} 
incalculable' ${ }^{67}$ Unjust detention can 'exact a heavy toll on its victims and their families' ${ }^{68}$ The psychological trauma can result in depression, anxiety, paranoia, drug or alcohol dependency, withdrawal and estrangement, and in serious cases, posttraumatic stress disorder and enduring personality change, that create severe mental health and adjustment problems. ${ }^{69}$

The impact of detention is a subjective experience and is not, necessarily, directly related to the length of such detention. For example, Marinko Katava was detained at the UNDU for 2 months before the case against him at the ICTY was terminated. The trauma of his detention, in what was a very security focused regime at the time, led him to design and erect a statue in his home town, Vitez, to testify to the fundamental importance of liberty. ${ }^{70}$

The impact of an international indictment on an individual's reputation will vary depending on the circumstances. For example, Mr Kenyatta was elected President of Kenya while being investigated by the ICC. Even where an individual maintains a public role, this does not mean there have not been defamatory reports and a presumption of guilt. For example, Mr Delalić, who became a regional Minister for Justice after release, recorded over 400 news articles calling him an international criminal during his detention. ${ }^{71}$ It seems that 'a person acquitted before an international criminal court is not an ordinary acquitted person: stigmatisation endures even after acquittal'. ${ }^{72}$ Unfortunately, this stigmatisation has more than reputational effects. For international acquitted persons, it can have serious legal and practical consequences that can result in continued deprivations of liberty and restrictions on freedom of movement.

\section{$\underline{2.5 \text { Relocation after release }}$}

The process of adjusting to life after long periods of detention has practical, financial, emotional and legal dimensions. The released person may not have access to money, whether due to their assets being frozen, the cost of defence, the lack of earnings or pension, or the use of savings to support their families during their custody. Spending time in detention in a foreign country will put strain on family relationships. Many international detainees only receive visits once or twice a year. Even with the ICC's more progressive and supportive approach to maintaining family

\footnotetext{
${ }^{67}$ Manns (n 62) 26.

${ }^{68}$ Huff cited in J. Chinn and A. Ratliff, " "I was put out the door with nothing" - Addressing the Needs of the Exonerated under a Refugee Model' (2008) 45 California Western Law Review 405, 416.

${ }^{69}$ See Grounds (n 66) 2, 3, 13, 15, 22-4, 41-2.

${ }^{70}$ Interview, Vitez (BiH, 6 October 2007).

${ }^{71}$ Written correspondence, 20 August 2008.

${ }^{72}$ J-P. Kilenda Kakengi Basila, 'The Case of Mathieu Ngudjolo: A Challenge for the ICC, the Host State and States Parties' (ICC-01/04-02/12-147-AnxD-tENG, 20 December 2013) 7. See also Nzuwonemeye ICTR-00-56-A (Motion for Compensation and Damages for Violations of the Fundamental Rights of F.X. Nzuwonemeye pursuant to SCRes 1966 (2010), MICT-13-43, 18 February 2015) paras 814 .
} 
relationships, ${ }^{73}$ communications are often restricted to letters and phone calls. Moreover, forms of adaption that are functional in the prison context may be dysfunctional and counter-productive in the post-release social and family context. ${ }^{74}$ Released persons may struggle with feelings of estrangement and loss, and find it difficult to restore previously close relationships. ${ }^{75}$ There may also be, foreseeably, significant relational, psychological, financial and even safety consequences for family members, spouses and children in particular. ${ }^{76}$

Readjustment may be even more difficult in a post-conflict setting. A study of 50 former fighters released from Padema Road Prison in Freetown after proceedings against them were terminated noted that their release into a volatile post-conflict environment without support to reintegrate meant that they simply moved 'from one form of confinement to another'. ${ }^{77}$ Jefferson explains that this continuity of confinement was created due to a lack of security, stigma and marginalisation. ${ }^{78}$ While some of the issues (freedom of movement and assembly) in this situation were caused by a lack of paperwork demonstrating that the individuals had no case to answer, ${ }^{79}$ physical release had not brought real freedom. ${ }^{80}$

The situation can become even more complicated for persons detained at the Host State of an international court. Past cases have demonstrated the long-lasting and significant impact an indictment by an international court can have on an individual. For some acquitted accused, they have returned home quietly, others to a hero's welcome. For others, the situation has not been so straightforward. Even when charges are dropped or an individual is acquitted, the international detention facility may not be able to release the individual immediately ${ }^{81}$ due to international travel bans imposed following an indictment. ${ }^{82}$ For some acquitted persons, the situation is much more serious than a delay in effecting release. For several persons acquitted on all charges by the ICTR, it meant moving from remand custody in an international detention facility (after pre-trial detention of seven - eight years) to custody in a safe house in the host State. ${ }^{83}$ The MICT has now assumed responsibility for the ICTR acquitted accused housed in Tanzania, some of whom have been seeking relocation for over eight years. ${ }^{84}$ Unable to return to their country of origin (Rwanda) due to

\footnotetext{
${ }^{73}$ See Reg 179(1) ICC ROR; R. Mulgrew, Towards the Development of the International Penal System (Cambridge University Press 2013) 113-115.

${ }^{74}$ Grounds (n 66) 3, 30 .

75 Ibid 2, 33-36.

${ }^{76}$ Manns (n 62) 28; J. Lonergan, 'Protecting the Innocent: A Model for Comprehensive, Individualised Compensation of the Exonerated' (2008) 11 Legislation and Public Policy 405, 407; Grounds (n 66) 37-9.

${ }^{77}$ A. Jefferson, 'Traversing sites of confinement: Post-prison survival in Sierra Leone' (2010) 14 Theoretical Criminology 387, 388.

${ }^{78}$ Ibid 389, 393.

${ }^{79}$ Ibid 395, 399.

${ }^{80}$ Ibid 389, 403.

${ }^{81}$ See Rule 99(A) ICTY/ICTR RPE (subject to the power to keep in detention pending an appeal by the Prosecutor - Rule 99(B) ICTY/ICTR RPE).

${ }^{82}$ Interview, Paddy Craig (ICCDC CCO, 4 July 2012).

${ }^{83}$ See B. Henry, 'The Acquitted Accused; a Forgotten Party of the ICTR' (2005) New England Journal of International and Comparative Law 81, 81.

${ }^{84}$ MICT Progress Report to the UNSC (16 November 2014-15 May 2015) S/2015/341 para 49.
} 
fears for their personal safety and the risk of persecution, ${ }^{85}$ and without the agreement of a third State to grant them asylum, ${ }^{86}$ they are confined to the four walls of a safe house in an unprecedented state of legal limbo. The restrictions placed on their movement and other rights mean that these acquitted persons consider the time spent in safe houses in Tanzania to be a continuation of their detention by the Tribunal. ${ }^{87}$ These acquitted accused persons have 'no travel documents, no passports, and no official legal status ( . . . ) [and] there is nothing in the Statute or the Rules governing the status or the social reintegration of the acquitted accused' ${ }^{88}$

There are both practical and legal obstacles. Without travel documents, these persons are restricted to making claims for asylum at embassies. However, as Heller explains, very few countries accept asylum claims made at their embassies. ${ }^{89}$ Even if the acquitted accused could access the territory of a State to request asylum, Heller notes that the State could refuse the request on the basis of the original indictment. The evidential burden required for an acquittal may still mean that significant doubt remains to their guilt which entitles States to invoke Article 1F of the Refugee Convention which enables countries to deny asylum to persons if there are 'serious reasons for considering' that they have committed a war crime or crime against humanity. ${ }^{90}$

In regards to their liberty status, they are no longer detained by the international court. But they are not free; they cannot freely move about in the host State and, indeed, there have been reports that the regime they are subject to in the safe house is stricter and less humane than the regime they were subject to in the UNDF. ${ }^{91}$ They remain separated from their families and friends. Despite their acquittal, these men continue to be viewed as international pariahs and genocidaires who pose a threat to order and security. ${ }^{92}$ In addition to the continuing stigma, these acquitted accused persons are 'serving time for crimes they have not committed. They are paying an unfair price for having been suspects' ${ }^{93}$

Given the fact that it was foreseeable that similar issues could occur for the ICC, ${ }^{94}$ it is disappointing that a stalemate situation arose in relation to the administrative status of Mr Ngudjolo at the ICC. Following his acquittal ${ }^{95}$ and the dismissal of the Prosecutor's application for his continued detention pending the

\footnotetext{
${ }^{85}$ See K.J. Heller 'What Happens to the Acquitted?' (2008) 21(3) Leiden Journal of International Law 663, 664-5, 668.

${ }^{86}$ See Henry (n 83) 85.

${ }^{87}$ A claim for compensation for illegal detention included the period spent in the safe house in Arusha. See Nzuwonemeye ICTR-00-56-A (Motion for Compensation and Damages for Violations of the Fundamental Rights of F.X. Nzuwonemeye pursuant to SCRes 1966 (2010), MICT-13-43, 18 February 2015).

${ }^{88}$ Henry (n 83) 84.

${ }^{89}$ Heller (n 85) 669.

${ }^{90}$ See Heller (n 85) 671, 677. (In fact, this ground was invoked by the Dutch Government to refuse asylum to Ngudjolo Chui, acquitted by the ICC - see below.)

${ }^{91}$ Henry (n 83) 84, 86.

${ }^{92}$ See Heller (n 85) 664, 668, 676.

${ }^{93}$ Henry (n 83) 88.

${ }^{94}$ Heller (n 85) 675.

${ }^{95}$ ICC-01/04-02/12-3-tENG (Judgment pursuant to Art. 74 ICCSt).
} 
appeal, ${ }^{96} \mathrm{Mr}$ Ngudjolo was released from the ICCDC. The ICC Registry had planned to house Mr Ngudjolo in a hotel until such time as travel plans were made for him in accordance with rule 185(1). ${ }^{97}$ Rule 185(1) ICC RPE and Article 48(1) ICC HQA place an obligation on the ICC's Registry to make arrangements for the transfer of an acquitted persons (or persons whose charges have not been confirmed) to a State that is obliged or agrees to receive the individual (or a State which has requested their extradition) and the Host State is bound to facilitate such transfers. These plans could not however be put in place until a UNSC Travel Ban pursuant to SCRes 1596 had been lifted, which required a receiving State to be found. ${ }^{98}$ What happened instead was that Mr Ngudjolo was arrested by Dutch police and brought to the airport to be deported back to the DRC. Mr Ngudjolo requested that the ICC grant him protective measures under Article 68 ICCSt and his relocation to a non-African country, specifically Belgium to facilitate a request for asylum. ${ }^{99}$ In addition, at the airport, $\mathrm{Mr}$ Ngudjolo filed an application for asylum. While this prevented his immediate deportation, it resulted in his detention at an administrative detention centre for asylum seekers from the 21 December 12 to 3 May 2013. Although he was released ${ }^{100}$ before the Appeals Chamber could rule on his request that the ICC require the Host State to release him into the ICC's custody for the purposes of attending his appeal, the AC ruled that it could not have reviewed the lawfulness of this detention or ordered release as it was not the competent body. ${ }^{101}$ In contrast to the ICTR situation, Mr Njudolo was free to reside and move freely within the State upon his release from the retention centre. ${ }^{102}$ It is important to note, that the Registry was responsible for $\mathrm{Mr}$ Ngudjolo (and monitoring his whereabouts) since his release from the retention centre. $^{103}$

\footnotetext{
${ }^{96}$ ICC-01/04-02/12-12 (Decision on the request of the Prosecutor of 19 December 2012 for suspensive effect (AC), 20 December 2012).

${ }^{97}$ Basila (n 72) 4.

${ }^{98}$ See Chui ICC-01/04-02/12, 22 (Registry's observations pursuant to regulation 24bis of the Regulations of the Court on the 'SECOND ADDENDUM to 'Defence request that the Appeals Chamber order the Victims and Witnesses Unit to execute and the Host State to comply with the acquittal judgment of 18 December 2012 issued by Trial Chamber II of the International Criminal Court, February 2013) para 4.

${ }^{99}$ ICC-O1/04-02/12-15-tENG OA (Urgent Defence Application for the international relocation of Mathieu Ngudjolo outwith the African continent and his presentation to the authorities of one of the States Parties to the ICC for the purposes of expediting his asylum application, 21 December 2012).

${ }^{100}$ The Rechtbank Den Haag ordered his release from the alien retention centre at Schiphol Airport on the grounds that 'alien retention, whilst an asylum procedure is on-going, cannot be continuous as no exceptions to the applicable law and procedure have been demonstrated'. See 'Situation in DRC', Chui ICC-01/04-02/12-69-Conf-Exp (Public redacted version of Registry's update on the situation in relation to Mathieu Ngudjolo Chui, 3 June 2013) para 1.

${ }^{101}$ See Chui ICC-01/04-02/12 A (Decision on Mr Ngudjolo's request to order the Victims and Witnesses Unit to execute and the Host State to comply with the acquittal judgment of 18 December 2012 issued by Trial Chamber II of the ICC, 27 May 2013 (public redacted 12 June 2013)) para 10. 102 'Situation in DRC', Chui ICC-01/04-02/12-69-Conf-Exp (Public redacted version of Registry's update on the situation in relation to Mathieu Ngudjolo Chui, 3 June 2013) para 3.

103 'Situation in DRC', Chui ICC-01/04-02/12-69-Conf-Exp (Public redacted version of Registry's update on the situation in relation to Mathieu Ngudjolo Chui, 3 June 2013) para 8; Basila (n 72) 3.
} 
This state of affairs has been blamed on a legal vacuum that arose due to the operation of two concurrent jurisdictions ${ }^{104}$ - the ICC's appellate jurisdiction and the Dutch court's administrative bench's power to rule on the right to remain in the country. Yet, it would seem that there were very clear treaty and regulatory provisions in place that set out who was responsible for Mr Ngudjolo's relocation (Rule 185 ICC RPE; Art. 48(1) ICC HQA). The ICC Appeals Chamber acknowledged this legal framework, ruling that the pending asylum application did not 'negate the Registrar's obligation to give effect to Mr Ngudjolo's acquittal pursuant to rule 185(1)' and instructed the Registrar to make transfer arrangements taking into account $\mathrm{Mr}$ Ngudjolo's views, including as regards his security situation. ${ }^{105}$ This would seem to reinforce the logical conclusion that the ICC's duty to relocate acquitted persons takes priority over the host State's right to deport illegal aliens. The Registry accepted this responsibility and promised that it would do so once an appropriate place to relocate him to had been identified, and the travel ban had been lifted. ${ }^{106}$ Interestingly, the Registry noted that should he be relocated before appeal proceedings, it would facilitate his appearance at status conferences requested by the AC by way of transfer or video-link. ${ }^{107}$

At this stage, his Defence Counsel asked 'what would have happened if ( . . .) [he] had not applied for asylum? He would have been deported irrespective of ' the governing legal framework. ${ }^{108} \mathrm{He}$ felt that the ICC should have insisted on compliance or referred the matter to the arbitral tribunal stipulated in article 55(2) HQA. ${ }^{109}$ Perhaps the ICC should have done so, given that following the affirmation of his acquittal by the Appeals Chamber in February 2015, Mr Ngudjolo was re-arrested by Dutch authorities and transferred to the airport where a flight had been scheduled to effect his deportation to the DRC. This happened without the prior knowledge of Mr Ngudjolo or his legal representatives, and in spite of his claims to the ICC Appeals Chamber that he was unable to return to the DRC, or indeed any African nation on account of his cooperation with the ICC and his testimony incriminating a head of an AU state, President Kabila. He stated that as he was now 'deemed a traitor' he was at risk from attack from both military and non-military groups. ${ }^{110}$ The issue remains, again, with the Dutch immigration authorities.

This event really undermines the bilateral treaty in place between the ICC and the Host State and creates a dangerous precedent for on-going cooperation in this regard. For acquitted accused persons (and the Court responsible for assisting them) it

\footnotetext{
${ }^{104}$ Basila (n 72) 3.

${ }^{105}$ See Chui ICC-01/04-02/12 A (Decision on Mr Ngudjolo's request to order the Victims and Witnesses Unit to execute and the Host State to comply with the acquittal judgment of 18 December 2012 issued by Trial Chamber II of the ICC, 27 May 2013 (public redacted 12 June 2013)) para 13.

${ }^{106}$ Situation in DRC', Chui ICC-01/04-02/12-69-Conf-Exp (Public redacted version of Registry's update on the situation in relation to Mathieu Ngudjolo Chui, 3 June 2013) para 5.

${ }^{107}$ Situation in DRC', Chui ICC-01/04-02/12-69-Conf-Exp (Public redacted version of Registry's update on the situation in relation to Mathieu Ngudjolo Chui, 3 June 2013) para 7.

${ }^{108}$ Basila (n 72) 5.

${ }^{109}$ Ibid 6.

${ }^{110}$ Appeals Chamber Transcript - ICC-01/04-02/12 - ICC-01/04-02/12-T-4-Red-ENG WT 21 October 2014 1/85 SZ A.
} 
creates the danger of continued detention and uncertainty in relation to the very basic question of which country they will live in upon release. This situation is unfortunate given the existence of an explicit legal framework establishing who is responsible for relocating such persons. Yet the practical and political obstacle that they are released onto the territory of a host State is unavoidable. Given these very real difficulties, the inclusion of a power to award compensation to acquitted accused persons must be welcomed.

\subsection{Conclusion}

Article 85(3) ICCSt is innovative and unique in the international legal arena. ${ }^{11}$ It provides a power to grant compensation to persons who have been deprived of their liberty, despite the fact that proceedings were later terminated or they were found not guilty of all counts charged, for the first time in international law. This power is necessary in the international criminal justice system given the lengthy detention faced by many accused persons pending the finalisation of their trials. In addition to its excessive length, the impact of this detention is aggravated by its implementation in a foreign country away from family and friends and the stigma attached to an international indictment. This lasting stigma can have devastating results for the individual's reputation, relationships, livelihood and, even (worryingly) their liberty and freedom of movement. The inclusion of article 85(3) attests to the recognition of the real, lasting and complex problems faced by the individual and his or her family, and bridges a gap in the remedies that were available to international courts.

\section{Bridging a remedial gap}

The adoption of Article 85(3) was important as it provided a statutory basis to address some of the problem outlined above, and in so doing, bridged a remedial gap in international (criminal) law. This section outlines the problems faced by international courts that did not have an explicit statutory power to grant compensation and the reluctance to grant traditional remedies demonstrated by the international judiciary.

\subsection{The consequence of a lack of inherent power}

While there are examples of national legislative schemes that provide compensation for the harm caused by the detention of persons who are released

\footnotetext{
${ }^{111}$ G. Bitti, 'Compensation to an Arrest or Convicted Person', in R. Lee (ed), The International Criminal Court: Elements of Crimes and Rules of Procedure and Evidence (Transnational Publishers 2001) 623,623
} 
following an acquittal or termination of proceedings, ${ }^{112}$ there was, prior to the ICCSt, no such scheme in international law. ${ }^{113}$ Indeed, the current human rights law provisions upon which Article 85(1) and (2) are based exclude remedies in situations where the detention was lawful and the defendant was acquitted. ${ }^{114}$ Because of this, and the receipt of requests for compensation from persons acquitted on all counts following lengthy periods of detention, the Presidents of the ICTY and ICTR wrote to the UNSC asking for amendments to the Tribunals' statutes that would facilitate such compensation. ${ }^{115}$ As the judges of the UN Tribunals acknowledged, Article 85(3) has no equivalent in international human rights law and it is not part of customary international law. ${ }^{116}$ That being said, these judges still felt that it would be in the interests of the Tribunals and the UN to award compensation to accused persons who are acquitted or who have proceedings against them terminated because of the 'particular circumstances' in which the Tribunals operate and the long periods of pretrial detention faced by accused persons.

It was unfortunate that this request was not accepted. Without an explicit statutory power to grant such compensation, the judges of these institutions felt they were unable to award a remedy in these circumstances. ${ }^{117}$ In contrast to the approach adopted where there has been a violation of an enumerated right, the judges of the ICTY and ICTR have rejected claims that they have an inherent power to grant a remedy in cases where there is no explicit underlying right, citing, inter alia, the fact that granting a remedy would go beyond their powers and create financial implications.

The Rwamakuba case demonstrates this dual approach and highlights the significance of the inclusion of Article 85(3). Despite spending nearly eight years in detention before being acquitted on all counts at both first instance ${ }^{118}$ and on appeal, Mr Rwamakuba's request for a remedy based on Article 85(3) ICCSt, ${ }^{119}$ was denied by both the Trial and Appeals Chamber. ${ }^{120}$ The Appeals Chamber agreed with the Trial Chamber's finding that there was no internal legal basis for such an award (either in the internal positive law or case-law) and it was not part of customary

\footnotetext{
${ }^{112}$ Schemes exist in Germany, Norway, Sweden, Denmark, Austria, the Netherlands, Italy and Latvia. See O. Triffterer, Commentary on the Rome Statue of the International Criminal Court $\left(2^{\text {nd }}\right.$ edn, Hart Publishing and Nomos 2008) 1501; Michels (n 54) 413.

${ }^{113}$ See Rwamakuba ICTR-98-44C-A (Decision on Appeal against Decision on Appropriate Remedy, 13 September 2007) para 10.

${ }_{114}^{114}$ See for example HRC General Comment No 32 on Article 14 para 53.

${ }^{115}$ See ICTY Annual Report 2002 (A/57/379 - S/2002/985, 4 September 2002) para 28 14; Zappalà, (n 2) 1582 .

${ }^{116}$ See Letter dated 19 September 2000 from the President of the ICTY addressed to the SecretaryGeneral, Annexed to Letter dated 26 September 2000 from the Secretary-General addressed to the President of the UNSC, S/2000/904; Letter dated 26 September 2000 from the President of the ICTR addressed to the Secretary-General, Annexed to Letter dated 28 September 2000 from the SecretaryGeneral addressed to the President of the UNSC, S/2000/925, 06/10/2000.

${ }^{117}$ See Ninth Annual Report ICTY (UN Doc A/578/379-S/2002/985, 4 September 2002) para 28.

${ }^{118}$ Rwamakuba ICTR 98-44C-T (Trial Judgment, 20 September 2006) Chapter IV.

${ }^{119}$ Rwamakuba ICTR-98-44C-A (Decision on Appeal against Decision on Appropriate Remedy, 13 September 2007) para 5.

${ }^{120}$ Rwamakuba ICTR-98-44C-A (Decision on Appeal against Decision on Appropriate Remedy, 13 September 2007) para 15.
} 
international law. ${ }^{121}$ In other words, the judges could not grant compensation for lengthy detention without an explicit statutory or regulatory provision or precedent upon which to base such an award.

This can be contrasted with the practice of relying on an inherent judicial authority to award remedies in instances of violations of recognised rights. Indeed, this inherent authority was relied upon to grant $\mathrm{Mr}$ Rwamakuba monetary compensation and non-monetary assistance for violations of his fair trial rights. ${ }^{122}$ This was in spite of opposition by the Registrar who argued, inter alia, that compensation could not be awarded in the absence of a statutory provision or rule, particularly given unsuccessful attempts by the Tribunals' Presidents to have the legal framework amended to facilitate such a power. ${ }^{123}$ The Appeals Chamber, dismissing these claims, ${ }^{124}$ based the inherent authority to grant a remedy for violations of fair trial rights on the statutory duty to ensure a fair trial and respect for the rights of the accused (Article 19(1) ICTRSt), the need to provide an effective remedy for human rights violations (derived from ICTR and ICTY case-law and international human rights treaty law), and previous decisions noting the authority of the Tribunal to award financial compensation for human rights violations. ${ }^{125}$ Where enumerated rights had been violated, the Appeals Chamber upheld the Trial Chamber's finding that

internal institutional considerations related to the execution of an order, including budgetary matters, are separate considerations from the Tribunal's authority to award an effective remedy in the form of financial compensation ( . . . ) Budgetary considerations cannot interfere with the Tribunal's authority to award financial compensation as an effective remedy for a human rights violation. $^{126}$

Both Chambers in this case, however, rejected the argument that they had an inherent power to award a monetary remedy for wrongful prosecution. Indeed, the Appeals Chamber referred to the failed attempt by the ICTR President to seek such express powers and budgetary resources from the UNSC. ${ }^{127}$ Without a violated

\footnotetext{
${ }^{121}$ Rwamakuba ICTR-98-44C-A (Decision on Appeal against Decision on Appropriate Remedy, 13 September 2007) para 10.

${ }^{122}$ See Rwamakuba ICTR-98-44C-A (Decision on Appeal against Decision on Appropriate Remedy, 13 September 2007) paras 17-18.

${ }^{123}$ Rwamakuba ICTR-98-44C-A (Decision on Appeal against Decision on Appropriate Remedy, 13 September 2007) para 20.

${ }^{124}$ Rwamakuba ICTR-98-44C-A (Decision on Appeal against Decision on Appropriate Remedy, 13 September 2007) para 24.

${ }^{125}$ Rwamakuba ICTR-98-44C-A (Decision on Appeal against Decision on Appropriate Remedy, 13 September 2007) paras 22, 26.

${ }_{126}$ Rwamakuba ICTR-98-44C-A (Decision on Appeal against Decision on Appropriate Remedy, 13 September 2007) para 30. For a contrasting view, see Judge Shahabuddeen's Partly Dissenting Opinion. He argued that judicial inherent authority could not be invoked to 'justify the acquisition of a wholly new function, more particularly one which involves the expenditure of monies provided by UN member States' (see para 5).

${ }^{127}$ Rwamakuba ICTR-98-44C-A (Decision on Appeal against Decision on Appropriate Remedy, 13 September 2007) para 10.
} 
enumerated right, there was no legal duty to provide an effective remedy. Without a legal duty to provide a remedy, there was no budget line to draw from.

The rejection of an inherent power to grant a remedy in such cases has resulted in claimants at other tribunals arguing for a remedy on the basis of violations of established rights. In a recent claim submitted to the MICT by an acquitted accused person, for example, while Article 85(3) was referred to, this was only to make the point that a broader approach to compensation has been adopted within the international criminal law context. The legal basis for the claim submitted was the breach of fundamental and explicit rights (notification of charges and undue delay). ${ }^{128}$ Moreover, the ICTR case-law outlined above was cited to support the argument that financial compensation could be paid for violations of the rights of accused persons even in the absence of an explicit statutory provision granting the judges the power to do so.

In light of the difficulties experienced at the ad hoc Tribunals because of the lack of both an explicit and inherent power to grant a remedy in such circumstances, Article 85(3) is a significant addition to the Rome Statute. Not only does this statutory provision provide a clear legal basis ${ }^{129}$ for the judicial power and the funds required to implement it, the form of remedy granted, compensation, may overcome another problem encountered at the UN Tribunals. Sonia Starr calls this phenomenon 'remedial deterrence'.

\subsection{A means to overcome remedial deterrence?}

Without a remedial provision akin to Article 85(3), the defendant's liberty is the only compensatory currency international courts possess. ${ }^{130}$ Convicted persons who have been detained illegally or for excessive periods due to delay can receive a sentence reduction. ${ }^{131}$ However, prior to judgment and sentencing, the traditional remedy for violations of fair trial rights and excessive or illegal detention is release with prejudice to the Prosecutor. At the ICTR, for example, the Appeals Chamber ordered that the case against Barayagwiza be dropped with prejudice for the Prosecution and the accused person's immediate release because of the egregious nature of the violations of the accused's rights (detention in Cameroon and the failure

\footnotetext{
${ }^{128}$ See Nzuwonemeye ICTR-00-56-A (Motion for Compensation and Damages for Violations of the Fundamental Rights of F.X. Nzuwonemeye pursuant to SCRes 1966 (2010), MICT-13-43, 18 February 2015).

${ }^{129}$ See Art. 21(1)(a) ICCSt.

${ }^{130}$ See S.B. Starr, 'Rethinking 'Effective Remedies': Remedial Deterrence in International Courts' (2008) 83 New York University Law Review 693, 758.

${ }^{131}$ See Partially Dissenting Opinion of Judge Emile Francis Short, Bizimungu, Mugenzi, Bicamumpaka, Mugiraneza ICTR-99-50-T (Judgment and Sentence, 30 September 2011) para 7. Similarly, the AC ICTR compensated Juvénal Kajelijeli for the 'serious violations of the Appellant's fundamental rights during his arrest and detention in Benin and the UNDF' by reducing the sentence imposed at trial of two terms of life imprisonment and a term of 15 years imprisonment to a single fixed term of 45 years, Kajelijeli ICTR-98-44A-A (Judgment, 23 May 2005) para 324.
} 
to bring the accused before a judge at the ICTR for four months). ${ }^{132}$ While release was an 'extreme measure intended as a sanction for the serious breaches of fundamental guarantees of which the Prosecution was found to be responsible, ${ }^{133}$ the political reaction, by Rwanda in particular, resulted in the Appeals Chamber reversing its decision to order release in a controversial revision proceeding. ${ }^{134}$ It still held however that the violations of the defendant's rights had occurred and if convicted, these would have to be taken into consideration in the determination of the sentence and if acquitted, that the accused should be adequately compensated for the unjust detention. ${ }^{135}$ As he was later convicted for inciting genocide, he was 'compensated at the penalty stage, ${ }^{136}$ receiving a reduced sentence (32 years instead of a life sentence). ${ }^{137}$

A similar situation has already arisen at the ICC. The Trial Chamber in the Lubanga case decided to stay proceedings ${ }^{138}$ and release ${ }^{139}$ the accused person on the basis of the Prosecutor's non-disclosure of exculpatory evidence (and its effect on the accused's right to a fair trial), although the Appeals Chamber later overturned these decisions. $^{140}$

Starr argues that the traditional remedies of release and retrial may go beyond the restitutionary goal of human rights law and result in a 'windfall'. ${ }^{141}$ Given their impact on the tribunals' mandate, operational capacity and stakeholders' interests, such remedies are untenable and prohibitively costly in the international criminal justice context. ${ }^{142}$ The practical and political constraints of a system based on State cooperation are so significant that the Tribunals 'are institutionally incapacitated from ex post recognition of criminal procedure violations that are serious enough to require a significant remedy'. ${ }^{143}$ Accordingly, the costs of traditional remedies are resulting in the international judiciary narrowly interpreting substantive rights, erecting procedural hurdles and imposing high evidential burdens to avoid hearing or

\footnotetext{
${ }^{132}$ Barayagwiza ICTR-97-19-AR72 (Appeals Chamber, Decision, 3 November 1999).

133 Zappalà (n 2) 1581.

${ }^{134}$ Barayagwiza ICTR-97-19-AR72 (Appeals Chamber's Review Decision, 31 March 2000).

135 Barayagwiza ICTR-97-19-AR72 (Appeals Chamber's Review Decision, 31 March 2000) para 71.

${ }^{136}$ Schabas (n 3) 967.

${ }^{137}$ Nahimana et al ICTR-99-52-T (Judgment and Sentence, 3 December 2003) para 1107; Nahimana et al ICTR-99-52-A (Judgment, 28 November 2007) paras 1086-1097.

${ }^{138}$ Lubanga ICC-01/04-01/06-1486 (OA13) (Judgment on the appeal of the Prosecutor against the decision of Trial Chamber I entitled 'Decision on the consequences of non-disclosure of exculpatory materials covered by Article 54(3)(e) agreements and the application to stay the prosecution of the accused, together with certain other issues raised at the Status Conference on 10 June 2008', 21 October 2008).

${ }^{139}$ Lubanga ICC-01/04-01/06-1418 (Decision on the release of Thomas Lubanga Dyilo, 2 July 2008).

${ }^{140}$ Lubanga ICC-01/04-01/06-1487 (OA12) (Judgement on the appeal of the Prosecutor against the decision of Trial Chamber I entitled 'Decision on the release of Thomas Lubanga Dyilo', 21 October 2008).

${ }^{141}$ Starr (n 130) 694-5, 703.

142 Ibid 710 .

${ }^{143}$ Ibid 741.
} 
accepting claims. ${ }^{144}$ This approach is evident in applications for provisional release, or claims that trials have been unduly delayed. ${ }^{145}$

Starr argues that, in the international criminal justice context, 'an absolutist approach to the right to an effective remedy may be self-defeating' as it may result in no remedy being awarded. ${ }^{146}$ Therefore, it is both appropriate and desirable to adopt an interest-balancing approach that permits departure from the requirement of full remedy in face of strong legitimate countervailing considerations related to the institutional objectives of and operational constraints faced by international courts. ${ }^{147}$ As 'defendants' interests in broad rights and remedies cannot always trump these competing considerations, ${ }^{148}$ she argues that international judges should be able to grant less costly partial remedies. This approach is preferable as it results in a remedy being granted.

If this reasoning is accepted, it could be argued that Article 85(3) represents an interest-balancing approach to remedies in the international criminal justice context. Rather than continuing the judicial fiction that violations of fair trial rights or the right to liberty are not occurring (due to the high costs of traditional remedies for such violations), Article 85(3) gives international judges the power to award compensation to acquitted accused persons to deal with the harmful consequences of excessive prejudgment detention in international remand centres. As Trial Chamber III of the ICTR observed, the significance of the principle established by Article 85(3) 'must be understood with reference to the right of any individual to freedom, including the corresponding principle that detention should remain exceptional or, at least, limited to what is reasonable and necessary'. ${ }^{149}$ Indeed, the normative basis for the compensation of acquitted accused persons in many domestic systems is the need to try to counter-act the (exceptional) harm caused by legitimate government action resulting in detention. ${ }^{150}$ Counteracting the negative consequences of lengthy periods of remand detention therefore appears to the implicit foundation for the remedial power granted by Article 85(3).

This approach is in line with European penal policy. The Council of Europe's Committee of Ministers has recommended that member States provide compensation to "persons remanded in custody who are not subsequently convicted of the offence in respect of which they were so remanded'. ${ }^{151}$ Despite recognising that a legal basis for remand may have existed, the compensation is advocated on the basis of the nonpunitive nature of remand in custody. ${ }^{152}$

\footnotetext{
${ }^{144}$ Ibid 695, 710.

${ }^{145}$ Ibid 696, 720-2.

${ }^{146}$ Ibid 740.

${ }^{147}$ Ibid 698, 739, 753 .

${ }^{148}$ Ibid 739.

${ }^{149}$ Rwamakuba ICTR-98-44C-T (Decision on Appropriate Remedy, 31 January 2007) para 29.

${ }^{150}$ See Michels (n 54) 416-7.

${ }^{151}$ Para 34(1) Recommendation Rec(2006) 13 of the Committee of Ministers to member States on the use of remand in custody, the conditions in which it takes place and the provision of safeguards against abuse (Adopted on $27^{\text {th }}$ September 2006 at the $974^{\text {th }}$ meeting of the Ministers' Deputies).

${ }^{152}$ Para 34 Explanatory Memorandum CM(2006)122 Addendum, 30 August 2006 (adopted at the $974^{\text {th }}$ Meeting of the Ministers Deputies, 27 September 2006).
} 
Michels argues that it is important to distinguish between distinct rights - the right to a speedy trial, the right not to be detained for an unjustifiably long period and any right to compensation for acquitted accused persons. ${ }^{153}$ As he rightly states, the two former rights operate independently from findings of guilt or innocence and the remedy granted deals only with the periods that exceed what is considered a reasonable period of time. ${ }^{154} \mathrm{He}$ notes that the latter remedy is awarded in relation to the entire period of detention. But, Article 85(3) does not provide claimants with an entitlement to compensation. This power resulted from a fusion of the normative and principled foundations of the human rights protections against undue delay at trial (right to a fair trial) and excessive detention (the right to liberty). In other words, it addresses the harm caused by encroachments on these rights without the need to find an illegal act or violation of an enumerated right.

\subsection{Operational efficiency and legitimacy}

Article 85(3) does not create a right but a remedial tool to deal with the 'lawful' but worrying (and almost inevitable) consequences of international criminal justice process. Article $85(3)$ is necessary to empower judges to counteract the negative consequences of international indictments, prosecutions and detention. This power is not only of benefit to the applicant, but it is likely to have collateral benefits for the operational efficiency of the Court, and ultimately its legitimacy.

A compensation scheme of this type may result in caution and increased propriety in international investigations and prosecutions ${ }^{155}$ and induce 'socially optimal ${ }^{156}$ levels of remand detention. Research has shown that contrary to the traditional view that it is preferable that a guilty person is found innocent than an innocent person being found guilty, this principle becomes weakened, even inverted, in situations where persons are accused of serious crimes. ${ }^{157}$ The crimes under the ICC's jurisdiction are of the upmost gravity and have affected large, if not immeasurable numbers of victims. A scheme that urges caution in a context in which a vocal and active victim lobby demands convictions should be welcomed. Despite the initial (political) reluctance to fund compensation schemes for persons indicted for international crimes, ${ }^{158}$ a scheme that results in a more cautious approach to prosecutions and the use of remand detention can make the international criminal justice system more cost-effective. ${ }^{159}$

\footnotetext{
${ }^{153}$ Michels (n 54) 412.

${ }^{154}$ See Partially Dissenting opinion of Judge Patrick Robinson in Mugenzi and Mugiraneza ICTR-9950-A (Judgment, 4 February 2013).

${ }^{155}$ See Beresford (n 30) 635; Sheehy (n 64) 986.

${ }^{156}$ G. Doménech-Pascual and M. Puchades-Navarro, 'Compensating Acquitted Pre-Trial Detainees' (2014) International Review of Law and Economics 1, 10.

${ }^{157}$ J.W. de Keijser, E.G.M. de Lange and J.A. van Wilsem, 'Wrongful Convictions and the Blackstone ratio: An empirical analysis of public attitudes' (2014) 16(1) Punishment and Society 32,34-5, 44.

${ }^{158}$ Bitti (n 111) 623; Beresford (n 30) 642.

${ }^{159}$ Manns (n 62) 61.
} 


\section{$\underline{3.4 \text { Conclusion }}$}

While Article 85(3) may ensure greater cautiousness and propriety in the ICC's prosecutorial strategy and use of remand detention, this remedial power should not be seen as a substitute for recognising and remedying violations of enumerated rights, however costly these remedies may be for the international courts' operations and mandate fulfilment. The strong human rights protection against, and remedies for, unlawful detention on account of its excessive length and unduly delayed trials are important deterrents against the abuse of coercive power (to prosecute and detain). ${ }^{160}$ Article 85(3) should not be used as a means to legalise or legitimise excessively lengthy detention or avoiding the costs of the true remedy for such rights violations by enabling international courts to essentially pay for human rights violations.

The introduction of a judicial power to deal with the realities of international detention prior to the finalisation of proceedings is vitally important. It provides judges with an explicit power to grant a remedy in the absence of an explicit or customary international human rights obligation to do so. This explicit statutory power means that any sums awarded have a direct budgetary source. It ensures equality of treatment: convicted persons can receive compensation in the form of sentence reduction for violations of their right to liberty or a trial within a reasonable time. ${ }^{161}$ Finally, this power recognises that the legality of detention does not detract from its detrimental impact on the individuals subject to it. The ability of ICC judges to use this power has, however, been greatly restricted by thresholds and criteria established in the Court's statute and rules.

\section{Eligibility for compensation under Article 85(3)}

Article 85(3) provides the ICC judges with a power to grant compensation to 'unjustly prosecuted ${ }^{162}$ persons. This section outlines how this power is constrained by explicit statutory and regulatory provisions that create strict eligibility criteria.

\subsection{Statutory thresholds}

Article 85(3) contains several explicit criteria which applicants for compensation must be able to demonstrate.

Firstly, the individual must have been released from detention following a final decision of acquittal or a termination of proceedings. Accordingly, a person who was not remanded in custody would not be eligible for compensation.

\footnotetext{
${ }^{160}$ See Starr (n 130) 758-9.

${ }^{161}$ Duch ECCC 001/18-07-2007 623-627, 631-633. Sentenced to 35 years in prison but only had to serve 19 - 5 year reduction for illegal military detention and 11 for time already served.

${ }^{162}$ This term is used by the ICTY and ICTR Judges in their respective letters to the UNSC.
} 
Secondly, if the claimant has been acquitted, the acquittal must be final. The Prosecutor can appeal an acquittal on the grounds of a procedural, factual or legal error. ${ }^{163}$ An acquitted person may be remanded in custody pending the outcome of the appeal, although this should only be in exceptional circumstances after consideration of a concrete risk of flight, the seriousness of the offence charged and the probability of success on appeal, ${ }^{164}$ although any decision of this kind can be appealed. ${ }^{165}$ If an acquittal is not appealed, it typically becomes final after 30 days. ${ }^{166}$

Thirdly, and significantly, the release from detention must have been ordered due to the discovery of a grave and manifest miscarriage of justice (GMMOJ). ${ }^{167}$ This term is not defined. The inclusion of both adjectives (grave and manifest) suggests a narrower cause of action than that created by Article 85(2) in cases of wrongful convictions. ${ }^{168}$ This implicit requirement of a higher tier of injustice is troublesome given that the term miscarriage of justice 'connotes a failing of monumental scale'. ${ }^{169}$

The deliberate inclusion of a narrower cause of action could be recognition of the fact than an acquittal (or termination of proceedings) is a remedy of sorts for mistakes in criminal justice process. However, as Sheehy argues, the concept of miscarriage of justice should cover all instances whereby the criminal justice process does not work properly, with serious adverse consequences for wrongly accused persons: ${ }^{170}$ persons acquitted following a prior conviction 'are merely further along the "continuum toward outrage", as other categories of accused may suffer many of the same burdens as those wrongly convicted'. ${ }^{171}$

When seeking compensation at the ICTR, Mr Rwamakuba and his counsel argued that a GMMOJ had occurred on the basis of two distinct grounds. Firstly, they argued that the Prosecution had relied on false and unsatisfactory evidence to arrest and prosecute him. ${ }^{172}$ The AC rejected this claim, stating no evidence or convincing arguments had been produced to substantiate these allegations. ${ }^{173}$ The second ground was based on the lengthy detention he had endured (due to failings in the collection and presentation of evidence) and the denial of his right to an expeditious trial (due to

\footnotetext{
${ }^{163}$ Art. 81(1) ICCSt.

${ }^{164}$ Art. 81(3)(c)(i) ICCSt. Both the Trial and Appeals Chamber rejected the Prosecutor's request to keep Mr Ngudjolo Chui in detention pending the finalisation of the appeal of his acquittal.

${ }_{165}$ Art. 81(3)(c)(ii) ICCSt.

${ }^{166}$ Rule 150 ICC RPE.

${ }^{167}$ A narrower cause of action also seems to apply at the STL. The STL equivalent provision, Rule 170(D) STL RPE (added November 2010, fourth revision), does not require a grave and manifest miscarriage of justice. The only pre-condition is a final judgment of acquittal. However, this may be poor drafting as it goes on to require a serious miscarriage of justice in cases of illegal arrest or detention. This would seem incompatible with human rights law that grants an enforceable right to compensation in such instances. This threshold would seem more likely to have been intended for the former instance of final cases of acquittal.

${ }^{168}$ See Triffterer (n 112) 1501.

${ }^{169}$ P. Ewick, 'The Scale of Injustice', in C.J. Ogletree and A. Sarat (eds), When Law Fails: Making Sense of Miscarriages of Justice (New York University Press 2009) 303, 303.

${ }^{170}$ See Sheehy (n 64) 992.

${ }^{171}$ Ibid (quoting from Kaiser).

${ }^{172}$ Rwamakuba ICTR-98-44C-A (Decision on Appeal against Decision on Appropriate Remedy, 13 September 2007) paras 8, 15.

${ }^{173}$ Rwamakuba ICTR-98-44C-A (Decision on Appeal against Decision on Appropriate Remedy, 13 September 2007) para 11.
} 
denials of requests for severance). ${ }^{174}$ This claim was also found to be unsubstantiated. ${ }^{175}$ Can it be inferred from this case that both grounds, if substantiated, would qualify as a GMMOJ at the ICC?

There have been instances where Appeal judges have been highly critical of convictions handed down at first instance. For example, in the case of Protais Zigiranyirazo, a unanimous AC stated that serious errors made by the Trial Chamber in relation to their statement of legal principles and handling of key evidence resulted in a miscarriage of justice that invalidated the guilty verdict. ${ }^{176}$ Indeed, it held that the conviction at first instance had 'violated the most basic and fundamental principles of justice'. ${ }^{177}$ Is this the type of decision that will be required to constitute a finding of a GMMOJ?

A further problem is caused by the statutory requirement for the grave and manifest miscarriage of justice to be demonstrated by conclusive facts. It is unclear what this will mean in practice.

Will the decision releasing the detainee suffice or will a separate hearing be required? Rule 173(2)(c) ICC RPE refers to notification of the decision of the Court concerning the existence of a grave and manifest miscarriage of justice. This would seem to indicate that the determination of the existence of such a fact is a duty for the Court alone. But the importance of such a finding would seem to necessitate the hearing of the views of the persons alleging the miscarriage of justice. However, the requirement of a separate hearing may result in the creation of a potentially insurmountable evidential burden on the applicant. How do you prove a 'grave and manifest' miscarriage of justice has occurred?

Further, will an acquittal based on a majority decision suffice? ${ }^{178}$ This is an even more difficult question if these statutory requirements reflect an implicit preference for claims from persons who are (or at least appear to be) factually innocent (see below).

For example the majority of first instance acquittals ${ }^{179}$ and those affirmed on appeal $^{180}$ at the ICTY were unanimous decisions. In the case of acquittals on appeal, however, there has been more discord. While the Appeals Chamber unanimously reversed the convictions of Zoran, Mirjan and Vlatko Kupreškić, ${ }^{181}$ Judge Liu disagreed with the majority decision to reverse Momčilo Perišić's conviction (and 27

\footnotetext{
${ }^{174}$ Rwamakuba ICTR-98-44C-A (Decision on Appeal against Decision on Appropriate Remedy, 13 September 2007) para 8.

${ }^{175}$ Rwamakuba ICTR-98-44C-A (Decision on Appeal against Decision on Appropriate Remedy, 13 September 2007) paras 13, 15.

${ }^{176}$ Zigiranyirazo ICTR-01-73-A (Judgment, 16 November 2009) para 73.

${ }^{177}$ Zigiranyirazo ICTR-01-73-A (Judgment, 16 November 2009) para 75.

${ }^{178}$ See Art. 74(3) ICCSt.

${ }^{179}$ Dragan Papić, Zejnil Delalić, Fatmir Limaj, Isak Musliu, Sefer Halilović, Miroslav Radić, Ljube Boškoksi, Ivan Cermak.

${ }^{180}$ Fatmir Limaj, Sefer Halilović, Ljube Boškoksi - although see the Partially Dissenting and Separate Opinion and Declaration of Judge Schomburg, Limaj, Bala and Musliu IT-03-66-A (Judgment, 27 September 2007).

${ }^{181}$ Kupreškić, Kupreškić, Kupreškić, Josipović and Šantić IT-96-16-A (Judgment, 23 October 2001).
} 
year sentence). ${ }^{182}$ In the Gotovina and Markač case, the acquittal came as the result of a slim 3-2 decision. ${ }^{183}$ In their dissenting opinions, Judge Agius and Judge Pocar were not only extremely critical of the majority's reasoning and verdict, ${ }^{184}$ they were perplexed as to why convictions had not been entered under alternate modes of liability. ${ }^{185}$ Judge Meron ruled out this course of action on the basis that it would be unfair to the appellants to be found guilty of crimes that were different from those they defended against, ${ }^{186}$ while Judge Robinson ruled it out as the fact finding required for new convictions did not come within the appellate function. ${ }^{187}$ These comments do not necessarily reflect a view that the appellants were considered to be factually innocent.

A similar situation arose at the ICC. Although Mr Ngudjolo's unanimous first instance acquittal ${ }^{188}$ was affirmed on appeal, this affirmation was also the result of a bare majority decision. While three judges affirmed the first instance decision on the basis that it had not been materially affected by a procedural, factual or legal error, ${ }^{189}$ Judge Tarfusser and Judge Trendafilova were highly critical of the majority's review of the alleged errors made by the Trial Chamber and concluded that the acquittal should have been reversed or amended and a re-trial ordered pursuant to Article 83(2) ICCSt. ${ }^{190}$

Do conclusive facts of a GMMOJ exist when a minority of judges express a view that, due to the gravity of the errors made by the Trial Chamber in reaching a not guilty verdict, ${ }^{191}$ a re-trial should be ordered? At the ICTY, Judge Robinson noted that a re-trial (an exceptional measure) would not be appropriate if it would be unduly oppressive to the appellants - which would be the case if the accused had already spent long periods of time in custody ${ }^{192}$ and a retrial would be lengthy and expensive. $^{193}$

\footnotetext{
${ }^{182}$ Dissenting Opinion of Judge Liu, Perišić IT-04-81-A (Judgment, 28 February 2013).

${ }^{183}$ See Gotovina and Markac IT-06-90-A (Judgment, 12 November 2012); J.N. Clark, 'Courting Controversy: The ICTY's Acquittal of Croatian Generals Gotovina and Markač' (2013) 11 Journal of International Criminal Justice 399-423.

${ }^{184}$ See Dissenting Opinion of Judge Carmel Agius, paras 1, 91 and Dissenting Opinion of Judge Pocar, paras 2, 39. Gotovina and Markac IT-06-90-A (Judgment, 12 November 2012).

${ }^{185}$ See Dissenting Opinion of Judge Carmel Agius, paras 71-2 and Dissenting Opinion of Judge Pocar, paras 31, 33, 36. Gotovina and Markac IT-06-90-A (Judgment, 12 November 2012).

${ }^{186}$ Separate Opinion of Judge Meron, para 6. Gotovina and Markac IT-06-90-A (Judgment, 12 November 2012).

${ }^{187}$ See Separate Opinion of Judge Robinson, paras 14-16. Gotovina and Markac IT-06-90-A (Judgment, 12 November 2012).

${ }^{188}$ Chui ICC-01/04-02/12-3-tENG (Judgment pursuant to article 74 of the Statute, 18 December 2012).

${ }^{189}$ Chui ICC-01/04-02/12 A (Judgment on the Prosecutors appeal against the decision of Trial

Chamber II entitled 'Judgment pursuant to article 74 of the Statute', 27 February 2015) para 296.

${ }^{190}$ Joint Dissenting Opinion of Judge Ekaterina Trendafilova and Judge Cuno Tarfusser, Chui ICC01/04-02/12 A (Judgment on the Prosecutors appeal against the decision of Trial Chamber II entitled 'Judgment pursuant to article 74 of the Statute', 27 February 2015) Annex A para 70.

${ }^{191}$ Partially Dissenting Opinion of Judge Tuzmukhamedov, Ndindiliyimana, Nzuwonemeye, Sagahutu ICTR-00-56-A (Judgment, 11 February 2014) para 6

${ }^{192}$ By the date of the appeal in this case, Gotovina had served one-third of the sentence imposed at trial, and Markač had served half.

${ }^{193}$ See Separate Opinion of Judge Robinson paras 18-19, Gotovina and Markac IT-06-90-A

(Judgment, 12 November 2012).
} 
This view did not prevent the ICTY Appeals Chamber, by majority decision, granting the Prosecutor's appeal of an acquittal in the case of Haradinaj, Balaj and Brahimaj and ordering a re-trial to facilitate the testimony of Prosecution witnesses. ${ }^{194}$ Judge Robinson felt that as the case had already been extended several times on account of the Prosecutor's concerns about witness intimidation, ordering a retrial went beyond the powers of the Appeals Chamber and constituted a dangerous precedent as it prioritised the Prosecution's right to present its case over the accused's right to an expeditious trial. ${ }^{195}$ Although TCI had unanimously acquitted Haradinaj (and ordered his release), ${ }^{196}$ and acquitted Balaj by a majority (and ordered his transfer back to serve the sentence he was serving prior to transfer to the ICTY), ${ }^{197}$ the AC ordered that they be remanded in custody pending the outcome of the retrial. ${ }^{198}$ The new trial chamber unanimously acquitted these parties on all counts contained in the retrial indictment. ${ }^{199}$ These parties faced seven years of uncertainty in relation to their fate. Does this make it a conclusive case of a GMMOJ? Does an acquitted person who has to be returned to serve a sentence for murder qualify for compensation under a discretionary scheme?

It is clear that the statutory provision lacks clarity in relation to defining elements of the compensation scheme it establishes. Rather than add clarity, the rules that provide the detail for the operation of the scheme create further hurdles for claimants to overcome.

\subsection{Regulatory requirements}

The procedure for requesting and awarding compensation is set out in Rules 173 and 174 . These rules contain several requirements that may become procedural bars for applicants.

The rules establish a strict six month time-frame for applications. ${ }^{200}$ While a short time-frame can ensure potential claimants seek redress in a timely fashion, closing the claim for the ICC within a reasonable period, ${ }^{201}$ there is a danger that it does not allow sufficient time for claimants to collate the evidence they need to substantiate their claim. ${ }^{202}$ This is particularly true given the context: claimants will just have been released from international custody in a foreign country after a wrongful prosecution. ${ }^{203}$ The six month time-frame, although replicated by the STL, ${ }^{204}$ seems short when compared to national law. For example, in Bosnia-

\footnotetext{
${ }^{194}$ Haradinaj, Balaj and Brahimaj IT-04-84-A (Judgment, 19 July 2010).

${ }^{195}$ Partially Dissenting Opinion of Judge Robinson para 32.

${ }^{196}$ Haradinaj, Balaj and Brahimaj IT-04-84-T (Judgment, 3 April 2008) para 502.

${ }^{197}$ Haradinaj, Balaj and Brahimaj IT-04-84-T (Judgment, 3 April 2008) para 503.

${ }^{198}$ Haradinaj, Balaj and Brahimaj IT-04-84-A (Judgment, 19 July 2010).

${ }^{199}$ Haradinaj, Balaj and Brahimaj IT-04-84bis-T (Judgment, 29 November 2012).

${ }^{200}$ Rule 173(2)(c) ICC RPE.

${ }^{201}$ See Beresford (n 30) 645

${ }^{202}$ See Lonergan (n 76) 420.

${ }^{203}$ See Sheehy (n 64) 997.

${ }^{204}$ Rule 170(D) STL RPE.
} 
Herzegovina, acquitted persons have three years to submit a claim for compensation to the State-level Ministry of Justice. ${ }^{205}$ The statute of limitations ranges from between 1-10 years in statutory compensation schemes for wrongful conviction in the US, with an average of 2.6 years (although the Innocence Project recommends 3 years). ${ }^{206}$

Debates during the drafting of the statute show that there was a lack of clarity about what the starting point for this time-frame should be. ${ }^{207}$ The rules state that the time begins to run from the date the applicant was notified about 'the decision of the Court concerning $(\ldots)$ the existence of a grave and manifest miscarriage of justice under Article 85, paragraph 3, ${ }^{208}$ It is unclear if this rule introduces a requirement for the acquittal or decision terminating proceedings to explicitly state that there has a grave and manifest miscarriage of justice, or if, following an acquittal or termination of proceedings and an indication from the acquitted person that they intend to apply for compensation, a chamber must sit to decide if that case qualifies.

The fact that the request must be made to the Presidency in writing (Rule 173(1)) would support a view that the request must occur after the proceedings that resulted in the acquittal or termination of proceedings. ${ }^{209}$ Some argue that it would be more reasonable to have deliberations on compensation decided by the same Chamber that acquits the individual or terminates proceedings, as this would speed up the decision and reduce the burden on the Court by reducing the number of 'microproceedings unrelated to the main object of its jurisdiction'. ${ }^{210}$ However this expedited format is excluded by the regulatory direction that the Chamber that decides upon eligibility and compensation must be composed with judges who have not participated in any previous judgment involving the applicant. ${ }^{211}$ Although the term 'judgment' is used in the English version, reference to the French version suggests that the drafters' intention was to preclude the involvement of judges involved in any relevant decision by the Court at any stage of proceedings. ${ }^{212}$

The written request must set out the grounds for the claim and state the amount of compensation sought (Rule 173(3)). An earlier requirement for applicants to submit [written] evidence substantiating the amount sought was deleted as it was considered burdensome and vague. However, it is likely that this will be required in practice by those seeking compensation under Article 85(3) as they have no right to such remedy, and so must persuade the judges that they fulfil the criteria and that their case represents a sufficiently exceptional circumstance for the judges to exercise their

\footnotetext{
${ }^{205}$ See E. Mackic, 'Bosnia's Freed Indictees in Line for Big Payouts' Balkan Insight' (Balkan Insight, 15 March 2011) <http://www.balkaninsight.com/en/article/bosnia-s-freed-indictees-in-line-for-bigpayouts $>$ accessed 5 August 2015.

${ }^{206}$ R.J. Norris, 'Assessing Compensation Statutes for the Wrongly Convicted' (2011) 2 Criminal Justice Policy Review 1, 13.

${ }^{207}$ Bitti (n 111) 627-8.

${ }^{208}$ Rule 173(2)(c) ICC RPE.

${ }^{209}$ Zappalà (n 2) 1584.

${ }^{210}$ Ibid 1584-5.

${ }^{211}$ Rule 173(1) ICC RPE. In contrast, the STL rules do not include this requirement of impartiality. See Rule 170(E) STL RPE.

${ }^{212}$ Bitti (n 111) 627.
} 
discretion. ${ }^{213}$ Claims at other international courts for compensation for violations of the right to liberty or right to a speedy trial have failed or been unsuccessful in securing the amount sought ${ }^{214}$ due to a failure to clearly set out the heads of and provide evidence to prove claims and establish causality. ${ }^{215}$

Finally, it seems that only the direct victim of the grave and manifest miscarriage of justice can apply for compensation. Although the rules state that 'anyone seeking compensation' can submit a request (Rule 173(1)), Article 85(3) only refers to the person who has been released from detention following a final decision of acquittal or a termination of proceedings. Relatives and heirs do not seem to have standing to make such a request, either in their own right or on behalf of their (deceased) relative. This restricted standing can be distinguished from the broader approach adopted in relation to applications to revise a conviction or sentence under Article 84 , which can be exercised by close family members. ${ }^{216}$ Zappalà has suggested that, in cases where the victim has died, the Prosecutor should file a request on their behalf. ${ }^{217}$ While it is clear that the primary claimant should be the direct victim of the wrongful detention, there are no obvious reasons why close relatives and heirs should not be entitled to claim on the victim's behalf. In any case, in the event of a death, relatives should be able to pursue a submitted claim and receive any sums granted. ${ }^{218}$ As it stands, however, it seems that claims for non-victims will be deemed inadmissible.

\section{Determining Eligibility Claims}

In addition to the strict eligibility criteria established by the statute and rules, this legal framework also imposes restrictions on the judicial discretion to award compensation. This section outlines the procedure for determining eligibility and analyses the fetters on judicial decision-making before advocating a reconsideration of this cautious approach.

\section{$\underline{5.1 \text { Procedure }}$}

The Presidency's role in relation to implementing Article 85(3) is 'a purely administrative one $(\ldots$ ) the Presidency has no power to reject the request and only

\footnotetext{
213 See ibid 629.

${ }^{214}$ For example, the ICJ ordered the Democratic Republic of the Congo to pay the Republic of Guinea less than $1 \%$ of the compensation sought in the case of Ahmadou Sadio Diallo due to a lack of supporting evidence. See M. Andenas, 'Ahmadou Sadio Diallo' (2013) 107(1) American Journal of International Law 178, 179-181 and G. Ulfstein, 'Awarding Compensation in a Fragmented System: The Diallo Case' (2013) 4(3) Journal of International Dispute Settlement 477, 477, 482.

${ }^{215}$ See D. Shelton, Remedies in International Human Rights Law $\left(2^{\text {nd }}\right.$ edn, Oxford University Press 2005) 247-9, 296, 313.

${ }^{216}$ See Bitti (n 111) 626.

${ }^{217}$ Zappalà (n 2) 1585.

${ }^{218}$ See Sheehy (n 64) 997; Norris (n 206) 13.
} 
designates a Chamber to consider the request'. ${ }^{219}$ Bitti suggests that the use of the word 'designates ${ }^{, 20}$ means the Presidency should nominate an existing three judge Chamber (either a Pre-Trial or a Trial Chamber). ${ }^{221}$ The designated Chamber can decide whether to hold a hearing or to determine the matter on the basis of the request and any written submissions from the Prosecutor or the applicant. Importantly, Rule 174(2) also states that a hearing must be held if so requested by either the Prosecutor or the applicant. This was added to avoid violating human rights in relation to the requirements of a fair trial. ${ }^{222}$ The STL rules differ in this regard: while the Chamber may hear the Prosecutor's views, the rules do not give the applicant the right to be heard. $^{223}$

The applicant is entitled to legal assistance during the procedure (whether there is a hearing or not). ${ }^{224}$ This provision was necessary given that the statutory right to assistance (Article 67) only extends to accused persons awaiting the determination of charges against them. What is not clear is whether or not this assistance will be provided for free. Human rights law would suggest that legal aid should be granted in such compensation claims if the applicant lacks means, it is necessary to ensure access to a court and to ensure equality of arms (especially in complex procedures). Bitti has argued that these factors would suggest that legal aid must be granted for indigent applicants claiming under Article 85(3) to ensure he or she is not placed 'at a substantial disadvantage vis-à-vis the Prosecutor'. 225

The decision on eligibility (and any award) must be made by majority decision (Rule 174(3)). The rules do not state that this decision be made public. This is in contrast to a human rights approach to due process and statutory directions in relation to other pronouncements of chambers of the Court. ${ }^{226}$ This is also unfortunate given the need to remove the stigma that attaches to wrongly accused persons.

The rules also fail to state that the decision needs to be reasoned. This issue was actually debated at length during the drafting of the statute. Unfortunately the requirement to provide reasons was deleted following a request from the Russian and Spanish delegation due to a perception that, as there was no right to such compensation, the judges should not be burdened with a requirement to set out their reasons. ${ }^{227}$ This is disappointing from a due process perspective, and seems contrary to contemporary human rights law. ${ }^{228}$ It is also unfortunate given that there is no practice in this regard to draw from. Moreover, human rights jurisprudence on compensation for unlawful detention and wrongful convictions has been criticised for its lack of analysis and a failure to articulate the principles governing the

\footnotetext{
${ }^{219}$ Bitti (n 111) 626.

${ }^{220}$ Rule 173(1) ICC RPE. See also Rule 170(E) STL RPE.

${ }^{221}$ Bitti (n 111) 627.

${ }^{222}$ Ibid 632.

${ }^{223}$ Rule 170(E) STL RPE.

${ }^{224}$ Rule 173(4) ICC RPE.

${ }^{225}$ Bitti (n 111) 630. This view that the rules will translate into a requirement to provide legal aid to indigent claimants is supported by Zappalà (n 2) 1583).

${ }^{226}$ Bitti (n 111) 633.

${ }^{227}$ Ibid.

${ }^{228}$ Ibid 634.
} 
determination of awards. ${ }^{229}$ The ICC should make its reasons for determining whether an individual is eligible for compensation clear. The judges should deliver reasoned decisions to ensure transparency and the development of a coherent set of principles on compensation.

Other delegates felt there was no need to include reasons for decisions, as they are final: decisions cannot be appealed.

$\underline{5.2 \text { Judicial discretion, exceptional circumstances and the consequences of assessing }}$ factual innocence

In contrast to paragraphs 1 and 2 of Article 85, which incorporate existing human rights remedies and provide directly accessible rights, paragraph 3 grants a judicial power to consider claims. In addition to the criteria discussed above, this discretion is further fettered by the statutory direction that the power to grant compensation should only be exercised in exceptional circumstances. This not only narrows the scope of the field, but it may also require an enquiry into the factual innocence of the claimant.

Limitations are often included in compensation schemes to try to prevent persons found not guilty due to a technicality or those considered factually guilty from receiving compensation. As Sheehy points out, 'factual innocence ( . . ) plays a central role in ( . . ) compensation claims, restricting the right to have a claim heard, acting as a device for burden allocation and 'gatekeeping' and determining deservedness of $(\ldots)$ compensation'. ${ }^{230}$ Just as it is possible to wrongfully convict, criminal justice process may also result in wrongful acquittals. ${ }^{231}$ Indeed, this potentiality is recognised by the ICCSt; it enables the Prosecutor to appeal an acquittal $^{232}$ and the Appeals Chamber to reverse the acquittal or order a re-trial if the first instance decision was unreliable or materially affected by a procedural, factual or legal error. ${ }^{233}$ In the context of international criminal trials in particular, there will be little support for a system that provides financial gains to persons who are considered to be factually guilty. As Beresford notes, however, 'an effective way to separate the truly innocent from those found not guilty has yet to be discovered'. ${ }^{234}$ The statutory right to be presumed innocent results in the onus being placed on the Prosecutor to prove an accused's guilt beyond reasonable doubt. ${ }^{235}$ Any requirement of proof of innocence from the claimant inverts this principle, reverses the burden of proof and risks undermining not only the presumption of innocence, but also the acquittal judgment itself.

\footnotetext{
${ }^{229}$ Shelton (n 215) 309-310.

${ }^{230}$ Sheehy (n 64) 993.

${ }^{231}$ See Doménech-Pascual and Puchades-Navarro (n 156) 4.

${ }^{232}$ Article 81(1)(a) ICCSt.

${ }^{233}$ Art. 83(2) ICCSt.

${ }^{234}$ Beresford (n 30) 635.

${ }^{235}$ Art. 66 ICCSt.
} 
The Statute states that it is for the Court to find the facts that there has been a grave and manifest miscarriage of justice. In the absence of a prior judicial determination of such facts, however, it is likely that the applicant will have to provide evidence. As Beresford notes, a claimant may not be able to prove his innocence due to factors beyond his control, such as the death of a witness. ${ }^{236}$ In addition, as previously mentioned, the judges that decide on eligibility cannot have participated in any previous judgment regarding the applicant. ${ }^{237}$ While it is true that 'judicial impartiality is both an essential organizing component of any legitimate judicial institution and a core right for persons brought before such an institution, ${ }^{238}$ this requirement may result in not only another proceeding, but also another review of the facts to determine whether the prosecution and subsequent detention was indeed a grave and manifest miscarriage of justice. A requirement of proof of innocence may therefore result in a further trial during which an individual who has already 'had to fight for their acquittal ( . . ) [having] to prove their innocence to a higher standard still'. ${ }^{239}$

A requirement to prove innocence could be 'disastrous for the administration of justice', ${ }^{240}$ as it would create two classes of acquittal: 'real' acquittal when compensation is awarded, and acquittal without compensation that would be tainted with a presumption of guilt. ${ }^{241} \mathrm{~A}$ refusal to award compensation to an acquitted person on the basis of continuing suspicions would have a potential defamatory effect $^{242}$ that would impose 'a reputational cost ( . . . ) [and] increased social stigma'. ${ }^{243}$ Such a scheme creates a risk of re-victimising claimants and deterring eligible persons from applying ${ }^{244}$ by introducing a 'de facto verdict of not proven $(\ldots$ ) [or] probable guilt'. ${ }^{245}$

The ECtHR has been highly critical of requirements of this kind in national compensation schemes. In Austria, for example, claimants had to dispel suspicions in order to receive compensation, and in Norway, claimants had to show that it was probable that they did not carry out the act that formed the basis of the charge. ${ }^{246}$ These requirements have been repeatedly criticised by the ECtHR, as a judicial determination that there is continuing suspicion as to guilt undermines the presumption of innocence protected by the Convention and violates Article $6 .{ }^{247}$ In an

\footnotetext{
${ }^{236}$ Beresford (n 30) 643.

${ }^{237}$ Rule 173(1) ICC RPE.

${ }^{238}$ H. Abtahi, O. Ogwuma and R. Young. 'The Composition of Judicial Benches, Disqualification and Excusal of Judges at the International Criminal Court' (2013) 11 Journal of International Criminal Justice 379, 380.

${ }^{239}$ Sheehy (n 64) 994.

${ }^{240}$ Beresford (n 30) 642.

${ }^{241}$ See Michels (n 54) 420; Sheehy (n 64) 994.

${ }^{242}$ Michels (n 54) 420.

${ }^{243}$ Doménech-Pascual and Puchades-Navarro (n 156) 7.

${ }^{244}$ See Michels (n 54) 421; Beresford (n 30) 643.

${ }^{245}$ Sheehy (n 64) 993.

${ }^{246}$ See para 2(1)(b) Austrian Compensation (Criminal Proceedings) Act 1969; Art. 444 Norwegian Code of Criminal Procedure Act 1981.

${ }^{247}$ For example in his concurring opinion, Judge Greve noted in relation to the Norwegian law that 'the result is that a well-intended provision - that has proved valuable in a significant number of cases for
} 
attempt to bring their law in line with these findings, Austrian and Norwegian law now states that compensation cannot be refused or reduced on the basis of suspicions if the accused person has been acquitted by a final decision on the merits. ${ }^{248}$ This jurisprudence has not, however, prevented the likelihood of guilt being a factor in judicial determinations; simply the explicit acknowledgement of the influence of this probability. ${ }^{249}$

National practice has demonstrated that a requirement to prove innocence often creates a higher evidential burden for those claiming compensation than is required to avoid conviction. ${ }^{250}$ In compensation statutes in the US, the most common burden of proof is 'clear and convincing evidence'. ${ }^{251}$ For Article 85(3), 'conclusive facts' of a grave and manifest miscarriage of justice are required. Zappalà has suggested that what will be required is not so much a determination of factual innocence but 'a more concrete judgment as to the overall justice of the outcome of the proceedings' ${ }^{252}$ What this means in practice, however, is not clear. Moreover, this appears to imply that a higher standard than 'on the balance of probabilities' is required. In fact, a requirement of conclusive facts seems more akin to a requirement to prove that a grave and manifest miscarriage of justice has occurred beyond reasonable doubt.

A due process approach would reject the imposition of such a heavy burden on claimants and insist that 'the only appropriate test is one based on the merits of the claim. ${ }^{253}$ Indeed some would contend that compensation should be based on a broader (legal) notion of innocence that connotes that the presumption of innocence has prevailed. ${ }^{254}$ According to Zappalà, the very fact that a grave and manifest miscarriage of justice has been found to have occurred should constitute an exceptional circumstance, and therefore, perhaps the draftsperson uses exceptional circumstances 'more as a wish than a limitation of the scope of the rule'. ${ }^{255}$

\section{$\underline{5.3 \text { Reconsidering the restrictions on judicial discretion }}$}

Article 85(3) is a welcome addition to the ICCSt. It introduces the potential to grant a remedy to persons who were not previously entitled to redress under

\footnotetext{
which it was intended - turns out as ill-advised and not compatible with the presumption of innocence'. O v Norway App no 29327/95 (ECtHR, 11 February 2003). See also Hammern v Norway App no 30287/96 (ECtHR, 11 February 2003). For the Austrian system see Sekanina v Austria App no 13126/87 (ECtHR, 25 August 1993) paras 30-31; Asan Rushiti v Austria App no 28389/95 (ECtHR, 21 March 2000) para 31; Lamanna v Austria App no 28923/95 (ECtHR, 10 July 2001) para 40.

${ }^{248}$ See Doménech-Pascual and Puchades-Navarro (n 156) 3. This article also contains a discussion of broader judicial discretion to grant or refuse compensation in other European systems (the Netherlands, Germany and Spain).

${ }^{249}$ See Michels (n 54) 421; Doménech-Pascual and Puchades-Navarro (n 156) 3.

${ }^{250}$ Doménech-Pascual and Puchades-Navarro (n 156) 2.

${ }^{251}$ Only one scheme one requires 'conclusive' proof. Others use the term preponderance of evidence. In some cases, only exculpatory DNA evidence was accepted. See Norris (n 206) 13.

${ }^{252}$ Zappalà (n 2) 1577.

${ }^{253}$ Sheehy (n 64) 993.

${ }^{254}$ Ibid 994.

${ }^{255}$ Zappalà (n 2) 1583.
} 
international law. However, as the ICTR judges recognised, Article 85(3) is a 'narrowly drafted provision'. ${ }^{256}$ The contribution this compensation scheme can make to international policy and practice is limited by the inclusion of explicit and excessive restrictions. This scheme entails a number of weaknesses, including 'strict eligibility requirements, high standards of proof, numerous disqualifiers and short time limits' ${ }^{257}$ Moreover, the judicial discretion it grants is severely fettered by the requirement of the virtually insurmountable threshold of exceptional circumstances. ${ }^{258}$

As Sheehy notes, 'deciding who is eligible to claim for compensation will be a defining element of any compensation scheme'. ${ }^{259}$ The current threshold however seems to raise the bar for eligibility too high. The legal framework currently in place creates a multi-tiered system to determine eligibility that considerably narrows the field of claimants that will qualify. In fact, Triffterer feels that the current thresholds will mean that 'ordinarily no compensation will be paid to persons acquitted by the Court, or against whom proceedings have been terminated before final judgment. ${ }^{260}$ This threshold will deter potential claimants and risks violating the presumption of innocence and undermining the integrity of the Court's judgments. Moreover, a system that operates on the basis of unreasoned decisions, that cannot be appealed, lacks transparency and fails to uphold the principle of equal treatment. ${ }^{261}$

To overcome these problems, the current legal framework should be revised and amended. The most important amendment would be the removal of the terms 'grave and manifest' used to describe the miscarriage of justice and 'exceptional circumstances'. Both terms convey the drafters' desire to restrict the scheme. ${ }^{262}$ However, as some delegates at the Rome Conference agreed, ${ }^{263}$ these requirements unnecessarily restrict the judicial power to make awards. The current test imposes a burden that 'may prove insurmountable, except to applicants who were the victims of the most abhorrent cases of prosecutorial misconduct. ${ }^{264}$ Rather than restrict initial eligibility, a better approach is for the statutory provision to create a cause of action, leaving decisions about deservedness (based on the merits) to the judiciary. Michels has recommended a similar course of action, advocating a discretionary power to award compensation to persons released from detention following a final decision of acquittal, where it is in the interests of justice to do so. ${ }^{265}$

In contrast to the restrictions on eligibility found in the ICCSt, the Council of Europe has suggested that eligibility should be curtailed in situations where 'either the

\footnotetext{
${ }^{256}$ Rwamakuba ICTR-98-44C-T (Decision on Appropriate Remedy, 31 January 2007) para 28.

${ }^{257}$ Norris (n 206) 3.

${ }^{258}$ The requirement of exceptional circumstances was removed in the test for provisional release at the

ICTs as it had resulted in no release being granted. See Trotter (n 44).

${ }^{259}$ Sheehy (n 64) 992.

${ }^{260}$ Triffterer (n 112) 1501.

${ }^{261}$ See Zappalà (n 2) 1583.

${ }^{262}$ See Schabas (n 3) 965.

${ }^{263}$ Note regarding part 8 and article 81 contained in the transmittal letter from the Chairman of the Committee of the Whole to the Chairman of the Drafting Committee dated 7 July 1998 (UN Doc A/CONF.183/13(Vol.III)) 320. See Schabas (n 3) 966.

${ }^{264}$ Beresford (n 30) 643.

${ }^{265}$ Michels (n 54) 422.
} 
person remanded had, by his or her behaviour, actively contributed to the reasonableness of the suspicion that he or she had committed an offence or he or she had deliberately obstructed the investigation of an alleged offence' ${ }^{266}$ In other words, compensation would not be required where 'the behaviour of such persons may have had a significant influence on the decision to remand them in custody'. ${ }^{267}$ An approach that bars claims from persons whose own (intentional or negligent) actions resulted in their detention or its prolongation can be found in national legislative schemes in Europe (Austria, Norway, Sweden and the Netherlands). ${ }^{268}$ Caution should be used when using attribution as a bar to eligibility given the risk of pressure from prosecutors or bad legal advice. ${ }^{269}$ Rather than act as a bar, attributability could be used to reduce the quantum of any award granted to claimants whose acts or omissions contributed to their detention. ${ }^{270}$ The curtailment of entitlement to redress on the basis of attribution of responsibility (as with the ICC and human rights approach to wrongful convictions) $)^{271}$ and reference to the legal grounds for remand detention seems more appropriate than a restriction based on political and pragmatic concerns.

\section{$\underline{5.4 \text { Conclusion }}$}

If 'grave and manifest' and 'exceptional circumstances' are retained, these terms must be defined and concrete tests established to determine if they exist. What length of detention or degree of prosecutorial impropriety is it necessary to establish to meet these thresholds? A practice direction or set of guidelines should be developed. Precise definitions and principles to govern decision-making will ensure a more transparent and fair system for adjudicating claims. The current procedure requires clarification on a number of other significant aspects. Is a determination of the likelihood of innocence required? If so, what standard of proof is required and on whom does the burden of proof lie? What constitutes 'conclusive facts'?

Without clear guidance, there is a danger that discretion will only be exercised in high profile cases that have created a political or popular reaction. It is important that all (potential) claimants are treated equally. The present scheme is overly restrictive and does not seem to accord with the policy objectives behind its introduction - to deal with the harmful consequences of the lengthy detention that results from international prosecutions. Reliance on (guided) judicial discretion, rather

\footnotetext{
${ }^{266}$ Para 34(2) Recommendation Rec(2006) 13 of the Committee of Ministers to member States on the use of remand in custody, the conditions in which it takes place and the provision of safeguards against abuse (Adopted on $27^{\text {th }}$ September 2006 at the $974^{\text {th }}$ meeting of the Ministers' Deputies)

${ }^{267}$ Para 34 Explanatory Memorandum CM(2006)122 Addendum, 30 August 2006 (adopted at the $974^{\text {th }}$ Meeting of the Ministers Deputies, 27 September 2006).

${ }^{268}$ See Doménech-Pascual and Puchades-Navarro (n 156) 3; Michels (n 54) 421.

${ }^{269}$ See Norris (n 206) 13; Lonergan (n 76) 417.

${ }^{270}$ See Sheehy (n 64) 998; Michels (n 54) 422-3.

${ }^{271}$ Art. 85(2) ICCSt, Art. 14(6) ICCPR; Art. 2, Protocol No 7 ECHR.
} 
than strict (but undefined) explicit criteria, to decide on eligibility will ensure the system can actually provide an effective remedy to counteract the harm caused.

\section{Rethinking redress}

If a claimant is deemed eligible for an award under Article 85(3), the designated Chamber must decide on the amount of compensation (if any) to award. ${ }^{272}$ This section explores the factors considered by judges in making this decision and what compensation, as a remedy, is meant to address. It proceeds to advocate a more holistic approach to the design and delivery of remedial justice that goes beyond financial recompense.

\section{$\underline{6.1 \text { Compensation }}$}

Compensation is a retrospective remedy that should provide damages for what has been lost as a result of the harm caused. ${ }^{273}$ This section examines what the remedy of compensation should entail, how the quantum of awards should be determined and how awards granted can be delivered.

\subsubsection{The remedy of compensation}

According to the Council of Europe's Committee of Ministers, compensation to persons who are not convicted of the offence for which they are remanded in custody could cover 'loss of income, loss of opportunities and moral damage'. ${ }^{274}$ In other words, both pecuniary and non-pecuniary damages can be sought.

Pecuniary damages would include financial recompense for lost past and future earnings and pensions, reductions in property values or property loss (taking account of inflation and the devaluation of currency), past and present pain, suffering and injury to physical and mental health, punitive fines, ${ }^{275}$ and legal fees and expenses. ${ }^{276}$

Non-pecuniary damages provide for moral injury and dignity violations such as harm to reputation, fear, humiliation and mental distress; loss of enjoyment of life; loss of consortium and interference with family relationships. ${ }^{277}$ As the intangible and

\footnotetext{
${ }^{272}$ Rule 175 ICC RPE.

${ }^{273}$ See Shelton (n 215) 291, 301.

${ }^{274}$ Para 34(1) Recommendation Rec(2006) 13 of the Committee of Ministers to member States on the use of remand in custody, the conditions in which it takes place and the provision of safeguards against abuse (Adopted on $27^{\text {th }}$ September 2006 at the $974^{\text {th }}$ meeting of the Ministers' Deputies).

${ }^{275}$ This could be an issue under Article 85(2) if a wrongfully convicted person has paid a fine issued pursuant to Article 77(2)(a). See R. Young, 'Fines and forfeiture in international criminal justice', Chapter 5 in this volume.

${ }^{276}$ See Shelton (n 215) 35-6, 292, 301, 313.

${ }^{277}$ Ibid 292, 307.
} 
subjective nature of these forms of harm can make them difficult to prove or reflect in monetary terms, such damages are often presumed. ${ }^{278}$

It is important to note the inclusion of the word 'any' in the Rule $175 .^{279}$ This was inserted to highlight the fact that such compensation is not a right but a discretionary power of the Chamber. ${ }^{280}$ In other words, overcoming the eligibility thresholds will not necessarily result in an award of compensation. This suggests that a declaratory judgment could be handed down. This is doubtful for several reasons. Firstly, there has been no violation of an enumerated right to make a declaration about. Secondly, the ECtHR's practice of refusing to award compensation for recognised violations of Article 5(5) (ruling that a declaration of violation provides just satisfaction) has received sustained criticism. ${ }^{281}$ Judge Robinson at the ICTY has argued that the formal recognition of a violation of the right to a fair trial (undue delay) does not provide a sufficient remedy, particularly where the breach is substantial and causes claimants psychological non-pecuniary damage: financial compensation is required in such cases. ${ }^{282}$ Finally, a decision to award no compensation to claimants that have established exceptional circumstances and the occurrence of a GMMOJ is unlikely to be considered appropriate given the objectives of the Court (ending impunity, respect for victims and human rights protection).

Compensatory damages could also be nominal (symbolic), but this too is unlikely to be appropriate under this scheme. The level of damages awarded should be proportionate to the harm caused, ${ }^{283}$ and it is important that 'real compensation and not mere damages must be awarded' ${ }^{284}$ It is unclear, however, what level of awards the drafters of Article 85(3) anticipated. Zejnil Delalic (detained for over two and a half years at the UNDU) sought $€ 255000$ euros in compensation for legal fees, suffering in detention, loss of earnings and the collapse of his construction business in Austria, while Vlatko Kupreskić sought a minimum of US \$10 million for the harm he suffered as a result of three years in detention. ${ }^{285}$ In a recent claim submitted to the MICT, although it was acknowledged that it was 'difficult to attach a price tag, ${ }^{\text {, }}{ }^{\text {to }}$ to

\footnotetext{
${ }^{278}$ Ibid 37, 248, 317-8, 343, 368; Ahmadou Sadio Diallos (Republic of Guinea v Democratic Republic of the Congo) (Judgment, 19 June 2012) para 24.

${ }^{279}$ Rule 175 ICC RPE.

${ }^{280}$ Bitti (n 111) 636.

${ }^{281}$ See S. Trechsel, Human Rights in Criminal Proceedings (Oxford University Press 2005) 496, 500; Shelton (n 215) 257.

${ }^{282}$ See Partially Dissenting opinion of Judge Patrick Robinson in Mugenzi and Mugiraneza ICTR-9950-A (Judgment, 4 February 2013) paras 6, 9, 11.

${ }^{283}$ See Semanza ICTR-97-20-A (Judgment, 20 May 2005) para 125; Rwamakuba ICTR-98-44C-A (Decision on Appeal against Decision on Appropriate Remedy, 13 September 2007) para 27.

${ }^{284}$ N. Jayawickrama, The Judicial Application of Human Rights Law: National, Regional and International Jurisprudence (Cambridge University Press 2002) 423.

${ }^{285}$ See Tinjak (n 65).

${ }^{286}$ See Nzuwonemeye ICTR-00-56-A (Motion for Compensation and Damages for Violations of the Fundamental Rights of F.X. Nzuwonemeye pursuant to SCRes 1966 (2010), MICT-13-43, 18 February 2015) para 7 at 14 .
} 
the loss of liberty, freedoms, income, reputation and family life, the claimant sought one million US dollars. ${ }^{287}$

The amount of compensation awarded by regional human rights courts to applicants claiming under provisions similar to Articles 85(1) and (2) are often lower than expected ${ }^{288}$ (although awards to applicants with successful claims of excessive delay at trial were significantly higher if the accused person was later acquitted when compared to awards granted to persons found guilty). ${ }^{289}$ Jurisprudence reveals that this could be attributed to the fact that many claimants seeking compensation for human rights violations often fail to clearly articulate or substantiate (with evidence or legal argumentation) the heads or items of their claims. ${ }^{290}$ Although it is not stated in the rules, it is likely that the claimant will have to (and should be advised to) provide specific, itemised grounds and demonstrate with evidence that the harm claimed both occurred and was caused by (or that it was reasonably foreseeable that it would be caused by) the charges and subsequent detention by the ICC. ${ }^{291}$ Though the burden of proof will generally fall on the claimant, it is possible for the burden to be shifted to the Prosecutor once causation has been established.

The judges, when considering the amount to award, are obliged to consider the consequences of the grave and manifest miscarriage of justice on a range of factors derived from human rights jurisprudence. ${ }^{292}$ It seems that only the consequences of the GMMOJ for the claimant must be considered, and not the causes. Given the operational realities faced by the ICC, miscarriages of justice are likely to be attributed to structural causes rather than the acts or omissions of individuals. ${ }^{293}$ Therefore although aggravated and punitive damages are theoretically available in addition to restitutionary damages under Article 85(3), they are unlikely.

\subsubsection{Determining the quantum of an award}

While the claimant may request a particular sum of compensation (Rule 173(4)), the amount (if any) to be awarded is to be determined by the designated Chamber (Rule 175). If the remedy is intended to address the consequences for the claimant on his personal, family, social and professional situation, ${ }^{294}$ these must be assessed.

The perceived impartiality of such assessment is crucial given that it will form the basis of the official response to a grave and manifest miscarriage of justice. While

\footnotetext{
${ }^{287}$ See Nzuwonemeye ICTR-00-56-A (Motion for Compensation and Damages for Violations of the Fundamental Rights of F.X. Nzuwonemeye pursuant to SCRes 1966 (2010), MICT-13-43, 18 February 2015) para 5 at 13.

288 Trechsel (n 281) 374.

${ }^{289}$ Shelton (n 215) 312.

${ }^{290}$ Ibid 352; Ulfstein (n 214) 478, 483; Andenas (n 214) 179-181; Partially Dissenting opinion of Judge Patrick Robinson in Mugenzi and Mugiraneza ICTR-99-50-A (Judgment, 4 February 2013) para 12.

${ }^{291}$ See Shelton (n 215) 247-9, 296.

292 See Trechsel (n 281) 501.

${ }^{293}$ See Sheehy (n 64) 990.

${ }^{294}$ Rule 175 ICC RPE. The STL rule repeats these factors verbatim - Rule 170(E) STL RPE.
} 
the deciding judges cannot have been involved in the claimant's trial at any stage, they are still officials of the institution responsible for the harm caused. Independent input is critical in a compensation scheme that depends on discretion and that does not allow for the review of decisions. Moreover, such assessments are difficult and complex and international judges will not necessarily have the expertise required to determine the impact of the miscarriage of justice and the quantum and form of redress required to address this harm. On account of the need to ensure impartiality and the complex nature of such assessments, it is recommended that a team of independent experts be appointed to carry out this task.

In addition to taking caution in relation to arriving at a suitable and sufficient sum for any award, it is also important that the levels of any awards granted are justified. Sums awarded without reason or reference to pre-established guidelines risk being considered arbitrary and unfair. ${ }^{295}$ Unfortunately, little guidance can be drawn from the jurisprudence of other international courts. The ICJ's discussion of the principles for determining the quantum of compensation has been criticised for being vague. ${ }^{296}$ The ECtHR has also been criticised. Shelton notes that it remains hard to observe the workings of any principled decision-making ${ }^{297}$ and that decisions on damages are often notable for their 'lack of analysis or articulation of principles in regard to assessing damages ( . . . ) the Court never discusses the basis for the awards it makes, leaving much to speculation'. ${ }^{298}$ The interpretation and application of the right to compensation in human rights law remains undeveloped in many respects ${ }^{299}$ and decisions often 'do not attempt to quantify the harm [or] award precise relief' ${ }^{300}$ Due to the lack of practice to draw from, and the need to ensure a fair system, the ICC should adopt a practice direction or guidelines to govern such decision-making and ensure that decisions include precise and principled reasoning to ensure the development of a coherent body of jurisprudence.

\subsubsection{Limiting the amount that can be awarded?}

In addition to the difficulties associated with arriving at the sum to award, compensation schemes also create budgeting problems. Accordingly, some domestic systems rely on grids to set or restrict amounts that can be awarded for pecuniary damages. ${ }^{301}$ National legislation can fix the amount that can be granted in relation to the time served in detention. ${ }^{302}$ In Bosnia-Herzegovina, for example, awards have

\footnotetext{
${ }^{295}$ Sheehy (n 64) 980.

${ }^{296}$ See Shelton (n 215) 293; Ulfstein (n 214) 478; Ahmadou Sadio Diallos (Republic of Guinea v Democratic Republic of the Congo) (Judgment, 19 June 2012).

${ }^{297}$ Shelton (n 215) 309.

${ }^{298}$ Ibid 310.

${ }^{299}$ R.C.A. White and C. Ovey, Jacobs, White and Ovey, The European Convention of Human Rights $\left(5^{\text {th }}\right.$ edn, Oxford University Press 2010) 241.

${ }^{300}$ Starr (n 130) 703.

${ }^{301}$ Shelton (n 215) 293.

${ }^{302}$ See Norris (n 206) 3. For example, US Federal Law sets this limit at $\$ 50000$ per year.
} 
been based on a per diem rate. ${ }^{303}$ Limits on the total amount that can be awarded, irrespective of the time actually served, are also possible. ${ }^{304}$ Fixed amounts can make it easier for judges to decide how much to award, for the institution to budget for potential claims and for claimants to predict the level of award they should receive. ${ }^{305}$ The idea of adopting a maximum amount for awards received support in relation to Article 85(3). ${ }^{306}$

However, setting such sums is difficult. They would need to be regularly reviewed and adjusted to ensure they reflect contemporary costs of living and inflation rises. Moreover, as Manns argues, while per diem or per annum rates of compensation might minimise administrative costs, they ignore the opportunity costs of detention and may result in the grant of symbolic or nominal sums that do not reflect the harm suffered by individuals. ${ }^{307}$ What a system that uses damage schedules gains by providing a 'simple, efficient and economical resolution of claims,' it loses by limiting claims to economic loss. ${ }^{308}$

Rather than adopt a fixed approach or limit the maximum amount that can be granted, the judges could be left to use their discretion. This would ensure that the award reflects the costs imposed on the individual claimant. This would also appear to be a fairer and fuller method of redress when considered in light of the problems of using what are necessarily arbitrary caps. ${ }^{309}$ The wording of Rule 175 would suggest that the judges are required to undertake a subjective assessment of the impact of the miscarriage of justice on the individual claimant rather than an objective approach that seeks to standardise the amounts awarded. The grant of judicial discretion to determine what amount is appropriate in each case enables the remedy 'to reflect the real costs of pre-trial detention more comprehensively'. ${ }^{310}$ Allowing for the recovery of all proximate or foreseeable damage can ensure a 'more complete recovery'. ${ }^{311} \mathrm{On}$ the other hand, reliance on wholly discretionary and individualised awards makes it 'extremely difficult to adequately budget $(\ldots$ ) and to ensure a consistent source of funding'. 312

A hybrid approach could be adopted that sets a floor and cap, as well as daily or yearly rates, but that also allows for additional recovery based on assessments of the opportunity costs for individuals. ${ }^{313}$ However, this does not remove the difficulties associated with fixing rates or limits. For the ICC, it will be very difficult to set limits

\footnotetext{
303 40-70 convertible marks per day. See Mackic (n 205).

${ }^{304}$ See Table 1 in Norris (n 206) 7; L.C. Boucher, 'Advancing the argument in favor of state compensation for the erroneously convicted and wrongfully incarcerated' (2006) 56 Catholic University Law Review 1069, 1087; J. Costa, 'Alone in the World: The United States' Failure to Observe the International Human Right to Compensation for Wrongful Conviction' (2005) 19 Emory International Law Review 1615, 1639; Lonergan (n 76) 420-2.

${ }^{305}$ Manns (n 62) 51.

${ }^{306}$ See Bitti (n 111) 635; Zappalà (n 2) 1585.

${ }^{307}$ Manns (n 62) 51.

${ }^{308}$ Sheehy (n 64) 998.

${ }^{309}$ Lonergan (n 76) 423.

${ }^{310}$ Manns (n 62) 51.

${ }^{311}$ Sheehy (n 64) 998.

${ }^{312}$ Costa (n 304) 1625.

${ }^{313}$ Manns (n 62) 52.
} 
that reflect the standard of living relevant to all potential claimants. For example, in making a recommendation for a floor and cap for awards for violations of Article 5 ECHR, Treschel opted for a per diem rate with a range of between $€ 50$ to $€ 1000$. He acknowledged that this range was 'both broad and very rough' but felt it was necessary to 'enable the cost of living in the relevant states to be factored in'. Yet he also argued that the most important consideration should be that 'the compensation is substantial enough to highlight the value of personal liberty'. ${ }^{314}$ In relation to the ICC system, Michels proposed that the amount of compensation should be fixed at a daily rate of $€ 70$. This does not seem to allow for differences in the cost of living or the varying impact the detention may have had on the individual.

What is interesting is that using this proposed sum (€70 per day), Michels calculated that in 2010, the ICTY would have been liable to pay $€ 790510$ in compensation to ten individuals who had, collectively, spent over 11000 days in custody. ${ }^{315}$ This calculation dispels concerns that such rights would have detrimental financial impact. This would amount to $0.34 \%$ of the annual budget of the ICTY. And this is assuming that all persons would qualify for compensation. Schemes based on narrow eligibility or judicial discretion, such as the one established by Article 85(3), are likely to be a 'negligible public expense'. 316

\subsubsection{Delivering financial compensation}

While it is not stated explicitly, any awards granted under Article 85(3), as expenses of the Court, would be payable from the funds of the Court. ${ }^{317}$ It is likely that any (successful) decision will state a total sum of compensation to be awarded to the claimant. There is no guidance about how such awards should be delivered. The sum could be transferred in a final lump sum. However, it is also possible to consider the use of regular instalments. While the payment of instalments might be considered an unjustifiably paternalistic approach if based on a view that the claimant is incapable of managing their own money, ${ }^{318}$ this approach may be warranted on two grounds. Firstly, it may be appropriate where it has been established that the claimant's needs may vary over time or where they cannot be identified or accurately assessed at the time of the claim and therefore require on-going and continuous assessment. In this case, it may be appropriate to award an initial sum to compensate for the time spent in detention and associated costs with further assessed yearly sums to cover on-going and arising needs. Secondly, a regular payment option may be easier for the budget to absorb. This should not be taken to detract from the fact that

\footnotetext{
${ }^{314}$ Trechsel (n 281) 501.

${ }^{315}$ Michels (n 54) 423.

${ }^{316}$ Sheehy (n 64) 989.

${ }^{317}$ Art. 114 ICCSt.

${ }^{318}$ See Lonergan (n 76) 426.
} 
international organisations have a duty to ensure they have finances in place to provide remedies where they have committed international wrongs. ${ }^{319}$

\section{$\underline{6.2 \text { Other forms of redress }}$}

As the previous section outlined, the rules focus on the determination of an amount (if any) of compensation to be awarded. The current legal framework does not therefore cater for non-compensatory or indeed, non-monetary redress. This differs from the broader approach adopted by the STL rules, which state that other forms of redress may be granted. ${ }^{320}$ As the consequences of a miscarriage of justices can be both erosive and cumulative, ${ }^{321}$ it may not be possible to restore the status quo ante with recourse to financial compensation alone. While compensation can have an 'ameliorative, restorative and therapeutic function', ${ }^{322}$ some feel that when dealing with the complex harm caused by the loss of liberty, this traditional, monetary remedy is inadequate. ${ }^{323}$ European penal policy recognises that 'although the damage suffered in many cases will require financial compensation, other forms of reparation may be more appropriate'. ${ }^{324}$ International policy states that international organisations should provide a range of remedies including restitution, reparation, compensation and satisfaction. ${ }^{325}$ Given the detrimental consequences of wrongful prosecution and detention, it may be necessary to ensure the availability of a form of remedy that can provide, inter alia, reputational repair, rehabilitative support and reintegration assistance. This section advocates moving beyond a solely monetary approach to remedies and proposes the adoption of a more comprehensive redress system.

\subsubsection{Remedial responsiveness}

Zdenkowski argues for a 'making amends' model of redress for wrongfully convicted persons, as 'it is not possible to reverse history and restore an individual with complete integrity to his former position'. ${ }^{326} \mathrm{He}$ argues, however, that it is 'possible to take account of what has happened and to attempt to be responsive to those changes'. ${ }^{327}$ This idea of being remedially responsive to the impact detention has had on an individual's life course has found expression in human rights law as 'proyecto de vida'.

\footnotetext{
${ }^{319}$ See Mulgrew (n 73) 313-14.

${ }^{320}$ Rule 170(D)-(E) STL RPE.

${ }^{321}$ Ewick (n 169) 304.

${ }^{322}$ Beresford (n 30) 634.

${ }^{323}$ See G. Zdenkowski, 'Remedies for Miscarriage of Justice: Wrongful Imprisonment' (1993) 5(1) Current Issues in Criminal Justice 105, 108.

${ }^{324}$ Para 34 Explanatory Memorandum CM(2006)122 Addendum, 30 August 2006 (adopted at the $974^{\text {th }}$ Meeting of the Ministers Deputies, 27 September 2006).

${ }^{325}$ See Mulgrew (n 73) 313-4.

${ }^{326}$ Zdenkowski (n 323) 107.

${ }^{327}$ Ibid 108.
} 
The I-ACtHR, basing this concept on autonomy, noted that remedies granted on this ground should reflect the irreparable loss or severe impairment of opportunities for professional and personal development caused by an encroachment on an individual's rights. ${ }^{328}$ In other words, claimants should be viewed as more than 'mere agent[s] of economic production'. ${ }^{329}$

Disappointingly, however, no award was made on this ground due to the difficulties of translating the concept into monetary terms: access to the court and the decision were held to constitute satisfaction. ${ }^{330}$ Despite this, the concept can be and has been utilised to provide a normative basis for non-monetary remedies. For example, in the Cantoral Benavides case, Peru was required to pay for a university scholarship and associated living costs to one of the victims. ${ }^{331}$ This concept could be developed to provide a principled basis for devising and awarding non-financial remedies at the ICC.

There is already practice of the grant of non-monetary remedies at the ICTR. In the Rwamakuba case, the Trial Chamber directed the Registrar to ensure that $\mathrm{Mr}$ Rwamakuba received, in addition to financial compensation, a public apology, assistance with resettlement for him and his family and with his children's education. ${ }^{332}$ This approach seems to take a rehabilitative approach to restitution that focuses on restoring a person's reputation and health, and assisting with their reintegration into society. ${ }^{333}$

\subsubsection{Reputational repair}

The social stigma associated with being a former international detainee will vary with each claimant. For some it has not prevented their appointment or continuation in government positions. ${ }^{334}$ An international indictment, arrest, prosecution and detention will often, however, attract global media attention. These actions, and the attendant publicity, can have a punitive and stigmatising effect that endures long after the formal termination of the international criminal justice process. ${ }^{335}$ Even for acquitted persons, or persons against whom proceedings have been terminated, the mere existence of formal accusations can result in an enduring

\footnotetext{
${ }^{328}$ Loayza Tamayo v Peru (Reparations) (27 November 1998) 42 IAmCtHR (series C). See also Shelton (n 215) 314.

${ }^{329}$ Separate opinion, Judges Cancado Trindade and Abvell Burelli. See Shelton (n 215) 251.

${ }^{330}$ Judge C.V. de Reux Rengifo dissented on this point, criticising the court for failing to grant an award. He felt that awards under this ground should be limited to changes of such a magnitude that they alter the foundations of life. He would have granted 124190 under this ground. See Shelton (n 215) 315-6.

${ }^{331}$ Cantoral Benavides Case (Reparations) (3 December 2001) 88 IAmCtHR (series C) para 6 Disposition.

${ }_{332}$ See Rwamakuba ICTR-98-44C-T (Decision on Appropriate Remedy, 31 Jan 2007) Disposition.

${ }^{333}$ See Shelton (n 215) 275.

${ }^{334}$ For example, Delalic (acquitted by the ICTY) is now a deputy justice minister in Herzegovina Neretva canton - see Tinjak (n 65).

${ }^{335}$ See B. Steels 'Forever Guilty: Convict Perceptions of Pre and Post Conviction' (2009) 21(2)

Current Issues in Criminal Justice 242.
} 
presumption of guilt. ${ }^{336}$ As a Deputy Registrar at the ICTR noted, although defendants 'can't get more innocent than seven or eight judges telling the world that they are innocent $(\ldots)$ [s]omehow, the fact that they have been indicted haunts them for the rest of their existence'. ${ }^{337}$ Heller argues that the international community should ensure that acquitted persons do not continue to 'suffer the legal stigma of being accused'. 338

Official apologies are often sought as a form of satisfaction. Apologies can both provide an explicit acknowledgement of the harm caused and prevent the same thing from happening again by creating awareness of the causes of the problem. ${ }^{339}$ Apologies can assist with reputational repair. So can simple practical steps such as making the fact of the acquittal or termination of proceeding as prominent on the websites of the international courts as the fact of their indictment. Publicity notices can also be placed in international and local media. For example, in Japan a grant of compensation to acquitted accused persons will be published in the official journal and three newspapers of the claimant's choice. ${ }^{340}$

Although it has been argued by international officials that a formal apology can suffice, ${ }^{341}$ an apology should be seen as supplementary or additional form of redress only and not a substitute for a proper remedy.

\subsubsection{Dealing with trauma}

It is necessary to recognise that the mental health needs of claimants 'may be complex and substantial'. ${ }^{342}$ Research has shown that wrongful detention can have long-lasting and significant consequences such as long-term personality change, posttraumatic stress and other psychiatric disorders. ${ }^{343}$ Accordingly, remedies should include psychological and psychiatric support services that address any trauma caused by the wrongful detention. ${ }^{344}$ Treatment needs can be immediate, to address specific conditions such as PTSD or depression, but also longer-term, requiring counselling to come to terms with the time lost on account of their deprivation of liberty. ${ }^{345}$ Although this latter form of trauma can have a long-term impact on the claimant's physical and mental health, it can be difficult to assess at the time of release. ${ }^{346}$ Rather than continually reassess such needs, the ICC could consider providing relevant

\footnotetext{
${ }^{336}$ See Beresford (n 30) 635.

${ }^{337}$ Heller (n 85) 680.

338 Ibid.

${ }^{339}$ Campbell and Denov (n 64) 156; Sheehy (n 64) 992, 998; Grant (n 63) 20; Grounds (n 66) 20.

${ }^{340}$ See Michels (n 54) 418; Sheehy (n 64) 984.

${ }^{341}$ Rwamakuba ICTR-98-44C-A (Decision on Appeal against Decision on Appropriate Remedy, 13 September 2007) para 21.

${ }^{342}$ Grounds (n 66) 44.

${ }^{343}$ See Norris (n 206) 4; Grounds (n 66).

${ }^{344}$ Chinn and Ratliff (n 68) 439.

${ }^{345}$ Grounds (n 66) 44.

${ }^{346}$ S. Armbrust, 'When money isn't enough: The case for holistic compensation for wrongfully convicted' (2004) 41 American Criminal Law Review 157, 178; Norris (n 206) 4; Lonergan (n 76) 428-230.
} 
persons with long-term or life-long medical insurance to cover the costs of any required interventions. ${ }^{347}$

\subsubsection{Reintegration support}

Wrongfully convicted persons in domestic criminal justice systems tend to 'fall on the periphery of any existing social service relief measures', 348 with little to nothing being done to 'ease the transition from prison to the real world'. ${ }^{349}$ The situation is worse in the international criminal justice system, where there is no support for any released person. ${ }^{350}$ Even the new conditional release system instituted by the SCSL, fails in this regard, focusing more on supervision than support. ${ }^{351}$ This means that acquitted accused (or persons against whom proceedings have been terminated) at the ICC will not have access to any established reintegration support measures. This is unfortunate given the lengthy periods of detention likely to be involved in such cases. In addition to the usual reintegration problems faced by released persons (institutionalisation, health and relationship issues), persons released following a grave and manifest miscarriage of justice at the ICC may also have to deal with resettlement in a post-conflict society still in transition.

Acquitted persons in the international context may require access to a scheme that can 'perform a stepping-stone function between prison and society and between war and peace'. ${ }^{352}$ Detention at the seat of the Court in The Hague may mean, however, that acquitted accused persons cannot benefit from national demobilisation, peace-building or reconciliation programmes in their country of origin. ${ }^{353}$ Moreover, a post-conflict society may not have a functioning probation system to provide support to released persons at a national level. This discussion assumes however, that the released persons can travel to their country of origin. Practice has shown that acquitted accused persons may face significant legal and practical problems that prevent their relocation.

\subsubsection{Relocation}

Release from detention following an acquittal at an international court has not always resulted in freedom. As the cases outlined in Section 2.5 above demonstrate, release following an acquittal can result in further custody in administrative detention, (threatened) deportation to a country were the individual fears persecution and

\footnotetext{
${ }^{347}$ Lonergan (n 76) 432; Armbrust (n 346) 174.

${ }^{348}$ Chinn and Ratliff (n 68) 417.

${ }^{349}$ Armbrust (n 346) 176.

${ }^{350}$ See Mulgrew (n 73) 102.

${ }^{351}$ See R. Mulgrew 'Projet sur vingt-cinq ans: une analyse du système de liberation conditionnelle du Tribunal special pour la Sierra Leone’ (2014) 27 Cahiers de la Sécurité et de la Justice 142-153.

352 Jefferson (n 77) 393.

${ }^{353}$ Ibid 393.
} 
restricted freedom of movement and association if they remain in the Host State. For Mr Ngudjolo, his 'acquittal instead became a nightmare. The trauma of his incarceration increased by the day ( . . ) [he was] on the verge of depression as he had trouble understanding how such treatment could be inflicted on an acquitted person' ${ }^{354}$ Serious detrimental consequences of a miscarriage of justice can therefore continue after an acquittal or termination of proceedings in the international criminal justice context. Despite an explicit and negotiated division of responsibility between the ICC and the Dutch government in relation to the duty to relocate, ${ }^{355}$ de facto statelessness and a legal limbo was imposed on the first person to be acquitted by the Court. As Heller argues, while the ICTR 'has proven admirably protective of its acquittees ( . . . ) acquitted defendants should not have to choose between living as virtual prisoners under international protection and returning home to face significant physical and legal dangers'. 356

The ICC, conscious of the need to deal with this issue, drafted a model agreement that can be entered between the Court and States in the 'event that a suspect acquitted by the Court would not be able to return to their State of nationality'. ${ }^{357}$ Like the ICTR, ${ }^{358}$ however, the ICC cannot oblige a State to grant asylum or residency rights: 'the reception of both an acquitted person and a protected witness is completely reliant on the voluntary cooperation of a State'. ${ }^{359}$ Cooperation in this regard remains vitally important, not only to protect the fundamental rights of acquitted accused persons, but also to ensure respect for the Court's judgments. ${ }^{360}$

\subsubsection{Re-entry support}

A finding of not guilty and subsequent release may only be the beginning of a long and difficult transition period. ${ }^{361}$ Persons who can claim under Article 85(3) are likely to have been released suddenly without the preparation, support and supervision normally provided to long-term prisoners due to be released in domestic systems. Such released persons can face the same challenges as other institutionalised persons, such as adapting to their regained freedom, changes in their family life and advances in technology. ${ }^{362}$ While most adapt to practical changes, such as new

\footnotetext{
${ }^{354}$ Basila (n 72) 3.

${ }^{355}$ Article 48(1) ICC HQA. See also Rule 185 ICC RPE. The STL has also included this provision in its agreement. See Article 43(1) STL HQA.

${ }^{356}$ Heller (n 85) 677-8.

${ }^{357}$ Report of the Court on cooperation ICC-ASP/10/40, 18 November 2011 (Assembly of State Parties, Tenth session New York, 12-21 December 2011) para 52.

${ }^{358}$ See 16th ICTR Annual Report para 54.

${ }^{359}$ Chui ICC-01/04-02/12, 22 (Registry's observations pursuant to regulation 24bis of the Regulations of the Court on the 'SECOND ADDENDUM to 'Defence request that the Appeals Chamber order the Victims and Witnesses Unit to execute and the Host State to comply with the acquittal judgment of 18 December 2012 issued by Trial Chamber II of the International Criminal Court, February 2013) para 4.

${ }^{360}$ See Henry (n 83) 87; Basila (n 72) 6, 7, 9.

${ }^{361}$ See Costa (n 304) 1617.

362 See Norris (n 206) 4.
} 
technologies, in relatively short periods of time, ${ }^{363}$ dealing with the impact of institutionalisation may take longer. They may also face problems associated with the operational difficulties faced by international courts.

Re-entry support in this context is therefore vital. The re-entry requirements of each individual should be assessed and such assessments should form part of the discussion about the appropriate form of redress to grant. Re-entry assistance will be required immediately before and after release, but also over the longer term.

It is foreseeable that persons who have been declared indigent and detained for long periods of time in a foreign country without access to paid work (or available funds due to asset freezing) will have immediate financial needs upon release. They will have to pay for somewhere to live, food, clothing, insurance etc. The ICC should consider granting immediate transition loans (which could be deducted from any award made) or a grant to cover reasonable reintegration expenses incurred during this interim period that could be claimed in addition to compensatory damages. ${ }^{364}$

Beyond these immediate basics, it can be more difficult to assess longer-term needs that may require other forms of assistance. It may be necessary to ensure that rather than view such support (only) as a remedy following a judicial decision on eligibility and merit, re-entry support should (also) be seen as an administrative responsibility of the Registry. It is already technically the Registry's responsibility to relocate such persons. Further, both the ICTR and ICC have practice of directly supporting and being responsible for acquitted accused persons who cannot be relocated. But the responsibility is broader than supporting acquitted accused persons stuck in this legal stalemate.

The potentially life altering consequences of international prosecution and detention discussed above will often necessitate more than financial recovery. This duty should be broadened to include all forms of reintegration support. The ICC's Registry along with the Presidency's Enforcement team should establish a Re-entry Team to ensure the enforcement of acquittal decisions and provide support to persons harmed by wrongful prosecutions.

A dedicated re-entry team could provide the coordinated and multi-disciplinary support such persons require. ${ }^{365}$ Rather than assess such needs in an adversarial hearing, mediation could be used to discuss compensation claims and negotiate an individualised support package. A specialist team could provide a tailored approach to post-custody transition by assessing and delivering support in relation to both immediate and longer-term reintegration needs. This would involve a range of tasks such as organising access to accommodation upon release, and helping to secure and implement relocation treaties with cooperating States.

\section{$\underline{6.3 \text { Conclusion }}$}

\footnotetext{
363 Armbrust (n 346) 176.

${ }^{364}$ See Lonergan (n 76) 424-5.

${ }^{365}$ Chinn and Ratliff (n 68) 407.
} 
Article 85(3)'s restrictive thresholds mean that persons deemed eligible are likely to have suffered a very significant degree of harm. If the underlying goal is to address the harmful consequences of international remand detention, the remedy should be tailored to provide meaningful support that helps claimants rebuild their lives. The ICC should seek independent and expert advice when assessing the quantity of compensation to award and the method of delivery. Guidelines should be developed to ensure a transparent and principled approach to decision-making. Further, the ICC should adopt a broader approach to remedy than simple compensation. In fact a more holistic scheme would appear to be required by evolving human rights jurisprudence, contemporary penological standards, international principles on international organisation responsibility, the ICJ operational context and an explicit internal regulatory duty to focus on the consequences. Using respect for human dignity as a base line, remedies should help to restore the individual's autonomy and reputation and assist with rehabilitative and reintegrative needs.

\section{Dealing with the Costs of Suspicion in International Criminal Justice}

Issues related to acquittals in the international criminal justice field are increasingly attracting attention. ${ }^{366}$ The inclusion of Article 85(3) ICCSt represented a statutory recognition of the problems faced by such persons at the UN Tribunals and the judicial inability to respond to their situation in the absence of a legal right to compensation under international law.

The lack of political willingness at the UNSC to grant this judicial power to the UN Tribunals (attributed to cost concerns and the temporary nature of these courts) was disappointing due to the priority these institutions placed on protecting the rights of accused persons. ${ }^{367}$ The power included in Article 85(3) may be viewed as a 'logical corollary ${ }^{, 68}$ to the due process approach adopted by the ICCSt that prioritises the presumption of innocence and the right to a fair trial. This new power in international (criminal) law bridges an important remedial gap. It reflects evolving law, policy and practice at both national and regional levels. It essentially provides the ICC with a scheme to address the costs of suspicion and related detention.

While the ability to address the real and harmful consequences of wrongful international prosecution and detention is a welcome addition, both the objectives and the scope of the scheme are uncertain. Is this new judicial power an innovative step towards recognising the harm caused by excessive reliance on, and length of, detention in international criminal justice, or is it a legitimacy lever to be used to respond (or not) to instances of intense political reaction to judgments? On the one hand, Article 85(3) can be viewed as a form of social insurance that (re-)distributes the burden of international criminal justice process across society (and to an

\footnotetext{
${ }^{366}$ See for example the project 'When Justice is Done' at

<http://www.whenjusticeisdone.org/index.php/acquittedd> accessed June 2015.

${ }^{367}$ See Beresford (n 30) 645.

${ }^{368}$ Sheehy (n 64) 984.
} 
institution with means to provide a remedy). ${ }^{369}$ By accepting responsibility for mistakes, the legitimacy of international criminal justice process and public confidence in its outcomes can be enhanced. ${ }^{370}$ Fairness also dictates the need for such a system on a number of grounds. As Beresford notes, it is illogical to compensate someone for an unlawful arrest but not for the harm caused by spending extended periods of time in detention. ${ }^{371}$ Moreover, convicted persons can offset the time they spend in pre-judgment custody against any sentence imposed. ${ }^{372}$

On the other hand, however, acquittals in the international criminal justice context have the propensity to be extremely controversial. ${ }^{373}$ The discretionary basis of Article 85(3) may enable the Court to withhold a remedy in sensitive cases. There is also a danger that the provision can be used to address the costly impact of excessive detention without directly recognising violations of the right to liberty and a fair trial, and thereby as a means to avoid traditional remedies of release or re-trial. The new judicial power should not be used to commodify or pay for infringements of fundamental rights. ${ }^{374}$ The scheme should not be used to implicitly invert the illegality of situations of excessive detention in international remand centres.

In relation to the scope of the scheme, the rules on eligibility and procedure will result in a very narrow range of potential claimants and a low likelihood of an award being made. The current eligibility thresholds (GMMMOJ and exceptional circumstances) should be removed. Guidelines and practice directions should be developed to define key terms, clarify requirements and set the foundation for principled decision-making. The appointed judges should be able to use their discretion to tailor the remedy to the individual claimant's needs.

In terms of the remedy that can be awarded, this requires independent and expert input. Moreover, the form of the remedy available should be broader than monetary recompense and the ICC should create a body tasked with the design and delivery of a comprehensive redress and support system that assists with reputational repair, rehabilitation and reintegration.

To conclude, Article 85(3) is to be welcomed as an innovative and progressive development in international criminal law. However, it remains unclear in what circumstances and for what purpose this scheme will be used. The scheme requires refinement, the removal of unnecessary obstacles and the form of available redress needs to be reconsidered.

\footnotetext{
${ }^{369}$ See H.S. Master, 'Revisiting the Takings-Based Argument for Compensating the Wrongfully Convicted' (2004) 60 NYU Annual Survey of American Law 97, 111; Sheehy (n 64) 985; DoménechPascual and Puchades-Navarro (n 156) 1; Michels (n 54) 414-5, 418.

${ }^{370}$ See Doménech-Pascual and Puchades-Navarro (n 156) 2; De Keijser, De Lange and Van Wilsem (n 157) 33; Beresford (n 30) 635; Michels (n 54) 417; Sheehy (n 64) 989.

${ }^{371}$ Beresford (n 30) 643.

${ }^{372}$ See for example Art. 78(2) ICCSt; Rule101(c) ICTY/ICTR RPE.

${ }^{373}$ See Clark (n 183) 400.

${ }^{374}$ See Shelton (n 215) 48, 270, 290, 292, 465.
} 
